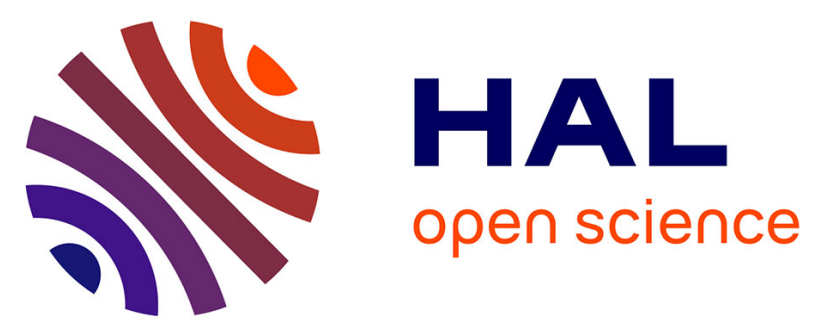

\title{
Major outputs of the recent multidisciplinary biogeochemical researches undertaken in the Aegean Sea
}

V. Lykousis, G Chronis, A Tselepides, N. B. Price, A. Theocharis, I.

Siokou-Frangou, France van Wambeke, R. Danovaro, S. Stavrakakis, G.

Duineveld, et al.

\section{To cite this version:}

V. Lykousis, G Chronis, A Tselepides, N. B. Price, A. Theocharis, et al.. Major outputs of the recent multidisciplinary biogeochemical researches undertaken in the Aegean Sea. Journal of Marine Systems, 2002, 33-34, pp.313-334. 10.1016/S0924-7963(02)00064-7 . hal-01780358

\section{HAL Id: hal-01780358 \\ https://hal.science/hal-01780358}

Submitted on 18 Feb 2021

HAL is a multi-disciplinary open access archive for the deposit and dissemination of scientific research documents, whether they are published or not. The documents may come from teaching and research institutions in France or abroad, or from public or private research centers.
L'archive ouverte pluridisciplinaire HAL, est destinée au dépôt et à la diffusion de documents scientifiques de niveau recherche, publiés ou non, émanant des établissements d'enseignement et de recherche français ou étrangers, des laboratoires publics ou privés. 


\title{
Major outputs of the recent multidisciplinary biogeochemical researches undertaken in the Aegean Sea
}

\author{
V. Lykousis ${ }^{\mathrm{a}, *}$, G. Chronis ${ }^{\mathrm{a}}$, A. Tselepides ${ }^{\mathrm{b}}$, N.B. Price ${ }^{\mathrm{c}}$, A. Theocharis ${ }^{\mathrm{a}}$, \\ I. Siokou-Frangou ${ }^{\text {a }}$, F. Van Wambeke ${ }^{\text {d }}$, R. Danovaro ${ }^{\text {e,f }}$, S. Stavrakakis ${ }^{\text {a }}$, \\ G. Duineveld ${ }^{\mathrm{g}}$, D. Georgopoulos ${ }^{\mathrm{a}}$, L. Ignatiades ${ }^{\mathrm{h}}$, A. Souvermezoglou ${ }^{\mathrm{a}}$, \\ F. Voutsinou-Taliadouri ${ }^{\text {a }}$ \\ ${ }^{a}$ Institute of Oceanography, National Centre for Marine Research, Ag. Kosmas 16604, Athens, Greece \\ ${ }^{\mathrm{b}}$ Institute of Marine Biology of Crete, Heraklion, Greece \\ ${ }^{\mathrm{c}}$ Department of Geology and Geophysics, University of Edinburgh, Edinburgh EH9 3JW, UK \\ ${ }^{\mathrm{d}}$ Microbiologie Marine, CNRS UMR 6117, Campus de Luminy, 13288 Marseille Cedex 9, France \\ ${ }^{\mathrm{e}}$ Department of Zoology, University of Bari, Bari, Italy \\ ${ }^{\mathrm{f}}$ Faculty of Sciences, University of Ancona, Ancona, Italy \\ ${ }^{\mathrm{g}}$ Netherlands Institute for Sea Research (NIOZ), P.O. Box 59, 1790 AB Den Burg, Texel, The Netherlands \\ ${ }^{\mathrm{h}}$ National Research Centre Democritos, Ag. Paraskevi, Athens, Greece
}

\begin{abstract}
The main outputs of a multidisciplinary and integrated studies are summarised. The results incorporate the latest biogeochemical researches, at basin scale, in the Aegean Sea (including thermohaline circulation studies, SPM dynamics, mass and energy fluxes, acknowledge biochemical processes in the euphotic and the benthic layer and benthic response to downward fluxes). The data were acquired within five (seasonal) research cruises, during 1997-1998. Data analysis and evaluation hence provided important new information on the functional processes of the Aegean ecosystem. In terms of water circulation, no new deep water formation in the Aegean Sea was observed, during 1997-1998, but rather intermediate water, due mainly to the mild winter conditions. All the biochemical parameters of the euphotic zone (nutrients, Particulate Organic Carbon (POC), chlorophyll- $a$, phytoplankton, primary and bacterial production), although high in the N. Aegean Sea reflect clearly the highly oligotrophic character of the Aegean Sea. In the N. Aegean, microbial food web was the main pathway of carbon, whereas in the S. Aegean, the food web could be classified as multivorous. An important Black Sea Water (BSW) signal was observed in the dissolved phase; this was especially pronounced in the Dissolved Organic Carbon (DOC), Mn and to a lesser degree to Cd, $\mathrm{Cu}$ and $\mathrm{Ni}$ concentrations. The downward material fluxes are higher in the N. Aegean, relative to the S. Aegean. Substantially higher values of near-bottom mass fluxes were measured in the deep basins of the N. Aegean, implying significant deep lateral fluxes of POM. The N. Aegean could be classified as a "continental margin" ecosystem, whilst the S. Aegean is a typical "oceanic margin" environment. There is a close relationship and, consequently, coupling between the near-bottom mass fluxes and the accumulation rates of organic matter (OM), with the near-bottom mineralisation, bioturbation, redox potential, oxygen consumption rates, the sediment microbiological and enzymatic activity and the meio-macro- and mega fauna abundances in the
\end{abstract}

\footnotetext{
* Corresponding author. Tel.: +30-1-9653520; fax: +30-1-9653522.

E-mail address: vlikou@fl.ncmr.gr (V. Lykousis).
} 
Aegean Sea. The N. Aegean is characterised by higher fluxes of labile POC and higher rates of benthic mineralisation and displays much higher benthic productivity and diversity relatively to the S. Aegean. The deep isolated N. Aegean basins should be regarded as "hot spots" of organic matter accumulation, benthic abundances and diversity. There is a general N-S gradient in the biogeochemical and benthic processes in the Aegean that is especially pronounced during winter-early spring, implied mainly by the of Black Sea Water (BSW) inflow (through the dissolved phase) and the lateral marginal inputs.

Keywords: Aegean Sea; Water formation; Biogeochemical cycles; Euphotic zone processes; Food web; Downward fluxes; Benthic coupling

\section{Introduction}

Due to a long-term geodynamic evolution and active neotectonics, the Aegean Sea displays a complicated physiography in terms of sea bed morphology and island configuration (Stanley and Perissoratis, 1977) (Fig. 1). The combination of the N. Aegean rivers and delta systems and the inflow of low salinity Black Sea Water (BSW, through the Strait of Dardanelles) together with the air-sea interaction processes creates within the Aegean Sea a $(\mathrm{N}-\mathrm{S}$ trending) complex system regarding its hydrology, water masses circulation, biological, chemical and sedimentological processes (N. Aegean prodelta platform-N. Aegean Trough-Central Aegean local deep sub-basins and islands-Cyclades Plateau-Cretan Basin-StraitsHellenic Arc). This system, together with the $\mathrm{N}-\mathrm{S}$ trend and spatial variability in the trophic conditions (Fig. 2) leads to a unique area for the study of biogeochemical fluxes.

The bottom topography of the N. Aegean is characterized by a series of SW-NE arranged deep trenches and troughs (with depths reaching $1500 \mathrm{~m}$ ), separated by shallow sills and shelves (Fig. 1). The N. Sporades Basin (1470 m deep) in the west, the Athos Basin (1149 m deep), the Limnos Basin (1590 m deep) and the shallower Saros basin (1061 m) in the eastern part. A 500-m-deep sill separates the Athos and the Limnos Basins. A shallow sill of $350 \mathrm{~m}$ separates the N. Aegean Trough from the 800-m-deep N. Skyros Basin (Central Aegean). The Cyclades Plateau and sills, which do not exceed than $350 \mathrm{~m}$ in depth, separate the Central from the S. Aegean.

There is a general cyclonic water circulation in the Aegean Sea. However, the most active dynamic features of the Aegean are the mesoscale cyclonic and anticyclonic eddies (Fig. 3). The inflow of BSW is the major source of brackish water for the N. Aegean, since the contribution of all the rivers discharging into the Aegean is less than the input of BSW by at least an order of magnitude (Poulos et al., 1997). The fluxes of the BSW in to the N. Aegean varies from 100 to 1000 $\mathrm{km}^{3}$ year $^{-1}$, whilst the net inflow in the Aegean is 300 $\mathrm{km}^{3}$ year ${ }^{-1}$ (Ovchinnikov et al., 1976; Ünlüata et al., 1990; Latif et al., 1991).

The $\mathrm{S}$. Aegean (Cretan Sea) is the largest in volume and the deepest $(2500 \mathrm{~m})$ basin of the Aegean Sea. The Basin communicates with the Levantine Basin and the Ionian Sea through the eastern and western straits of the Cretan Arc, respectively, through sills varying in depth from 150 to $1100 \mathrm{~m}$. To the north of the Cretan Basin is the shallow (less than $200 \mathrm{~m}$ ) shelf of the Cyclades Plateau. The hydrology and water mass dynamics of the S. Aegean Sea are known from historical studies of Nielsen (1912), Lacombe et al. (1958), Ovchinnikov (1966) and, recently, from the analysis of the data gathered within the framework of international, national and European programs, such as POEM, PELAGOS and CINCS (Georgopoulos et al., 1989, 2000; Theocharis et al., 1993, 1999a; Roether and Schlitzer, 1991; Balopoulos and Collins, 1999). These investigations have revealed the intense mesoscale variability that characterises the circulation pattern in the S. Aegean Sea and the Cretan Arc straits region (Fig. 3). A succession of transient and/or recurrent cyclonic and anticyclonic eddies defines the water mass distribution. Winter convection processes lead to intermediate and/ or deep water mass formation. In the mid- and late 1980 s, the upper layer in the S. Aegean was occupied by either the surface saline $(S \sim 39)$ waters of Levantine origin (LSW) (occurring during the warm period of the year, within the upper 50 dbar layer, and entering the SE Aegean through the eastern Cretan Arc Straits) or the less saline $(S<38.9)$ surface waters of Black Sea origin (BSW) (coming from the N. 


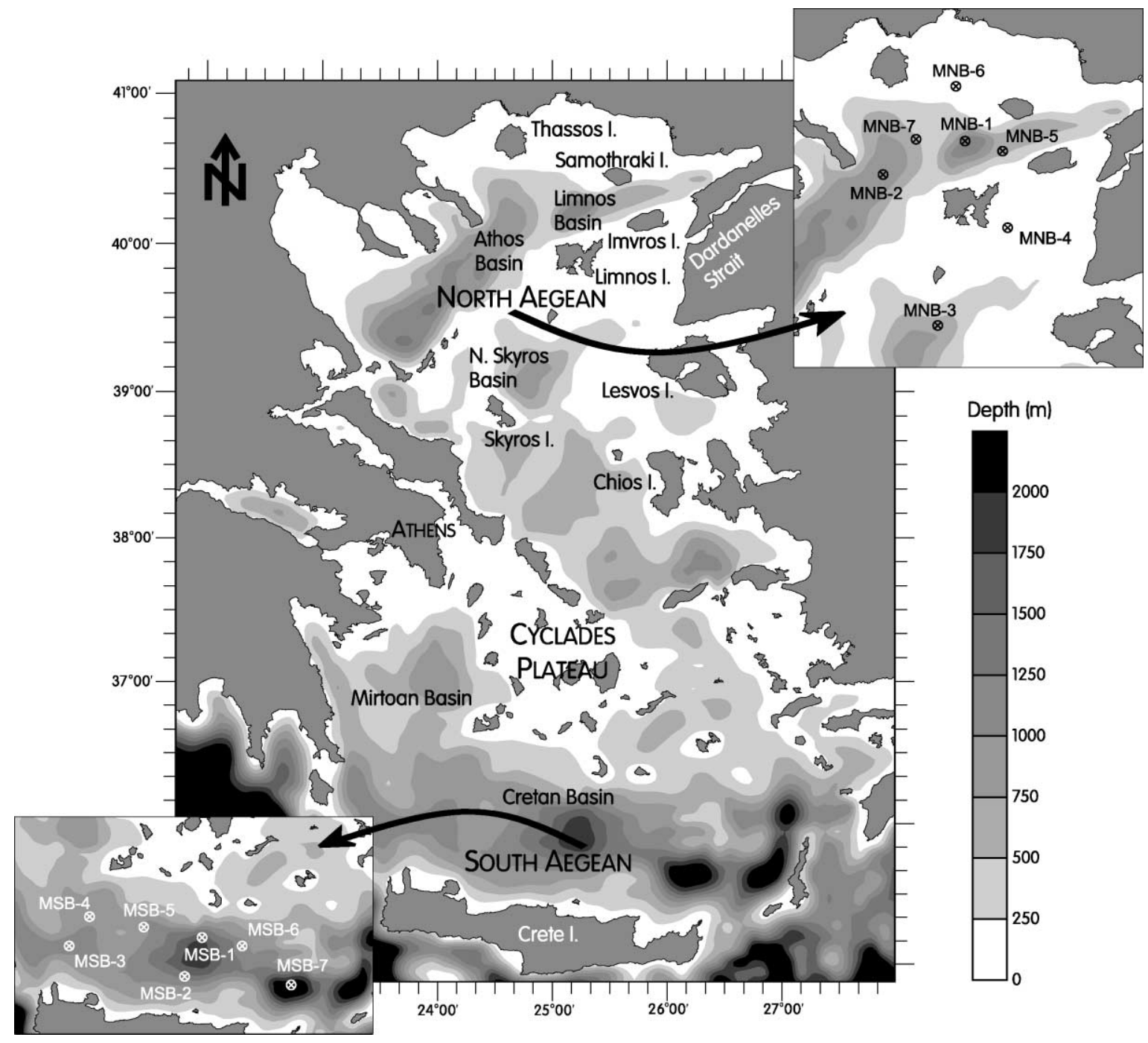

Fig. 1. General location map of the study area showing the sampling locations.

Aegean and affecting mainly the western Mirtoan and western Cretan Sea). Moreover, most of the time, there were intrusions through the Cretan Arc Straits of the less saline subsurface water of Atlantic origin, the so-called Modified Atlantic Water (MAW) originating from the Ionian Sea. Below the upper layer and down to the bottom, two water masses were distinguished with similar characteristics, but slightly denser ( $\sigma \theta$ up to 29.16) than those of the Levantine Intermediate Water (LIW). This relatively dense Cre$\tan$ water overflowing occasionally to the Cretan straits contributed to the water masses below the LIW in the Eastern Mediterranean.

In the early 1990s, the structure of the Cretan Sea water column changed dramatically, as exceptionally dense $(\sigma \theta>29.2)$ and very saline $(S>39 \mathrm{psu})$ water, of local origin, started filling the deep Cretan Basin and overflowing through the sills of the Cretan Arc straits (Kontoyiannis et al., 1999; Theocharis et al., 1999a; Roether et al., 1996). Due to its high density, the Cretan Deep Water displaced water from the deepest parts of the Levantine and Ionian basins of the Eastern 
(a)

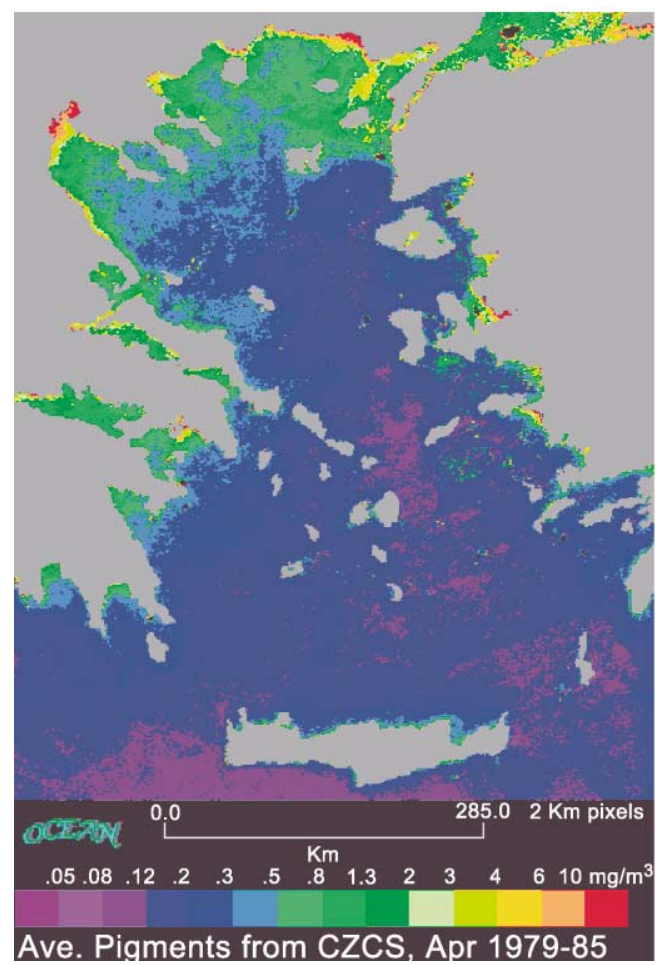

(b)

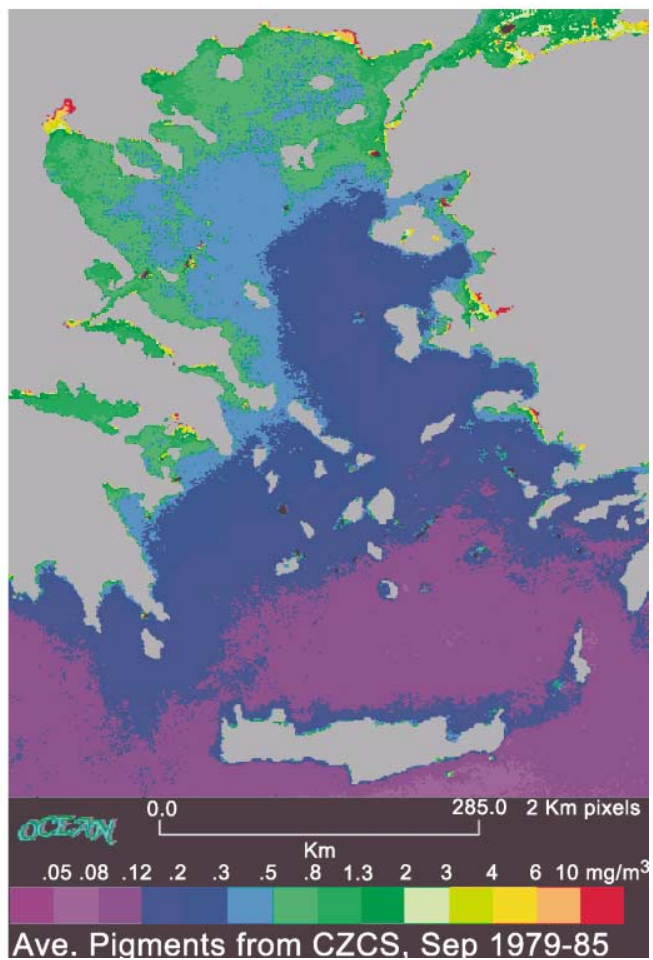

Fig. 2. Spatial and temporal variation in the productivity of the Aegean Sea as indicated by the CZCS images (averages) of the surface fluorescent pigments, during April (a) and September (b) (from Duineveld, unpublished, final report of MTP-II-MATER).

Mediterranean. Thus, the Aegean became the major contributor of deep/bottom, warmer, more saline water to the Eastern Mediterranean. The S. Aegean is also the site of the Cretan Intermediate Water (CIW) formation that leads to ventilation of either the Levantine Intermediate Water (LIW) horizons and/or the relatively deeper layers below the LIW in the Eastern Mediterranean (Georgopoulos et al., 1989; Roether and Schlitzer 1991; Theocharis et al., 1999a,b). Therefore, in recent years, three distinctive water masses were identified within the upper layer of the S. Aegean Sea, the LSW, BSW and MAW and three in the intermediate and deep layers: the CIW, formed locally and located between 50 and $250 \mathrm{dbar}$, with physical characteristics similar to those of the LIW, but still warmer and slightly saltier; in the deeper layers, the so-called Transitional Mediterranean Water (TMW), found a depths up to 700 dbar, coming from the mid-depths of the Eastern Mediter- ranean (a mixture between the LIW and the Eastern Mediterranean Deep Water) through the eastern and western Cretan Arc Straits; and, finally, in the deepest/ bottom parts (800-2500 dbar) the Cretan Deep Water (CDW) formed locally and/or in the surrounding shelf areas.

Biological and chemical processes taking place in the Aegean are affected by these environmental changes, but multidisciplinary information on this subject for the entire Aegean still does not exist. Most of the studies undertaken have been either unidisciplinary or limited regionally to the Cretan Sea (Price et al., 1999; Christaki et al., 1999; Danovaro and Serresi, 2000; Danovaro et al., 1998, 1999a,b,c, 2000a,b; Ignatiades, 1976, 1998; Ignatiades et al., 1995; Obernosterer et al., 2000; Pitta and Giannakourou, 2000; Psarra et al., 2000; SiokouFrangou et al., 1990, 1997; Souvermezoglou et al.,1999; Tselepides and Polychronaki, 2000; Tsele- 


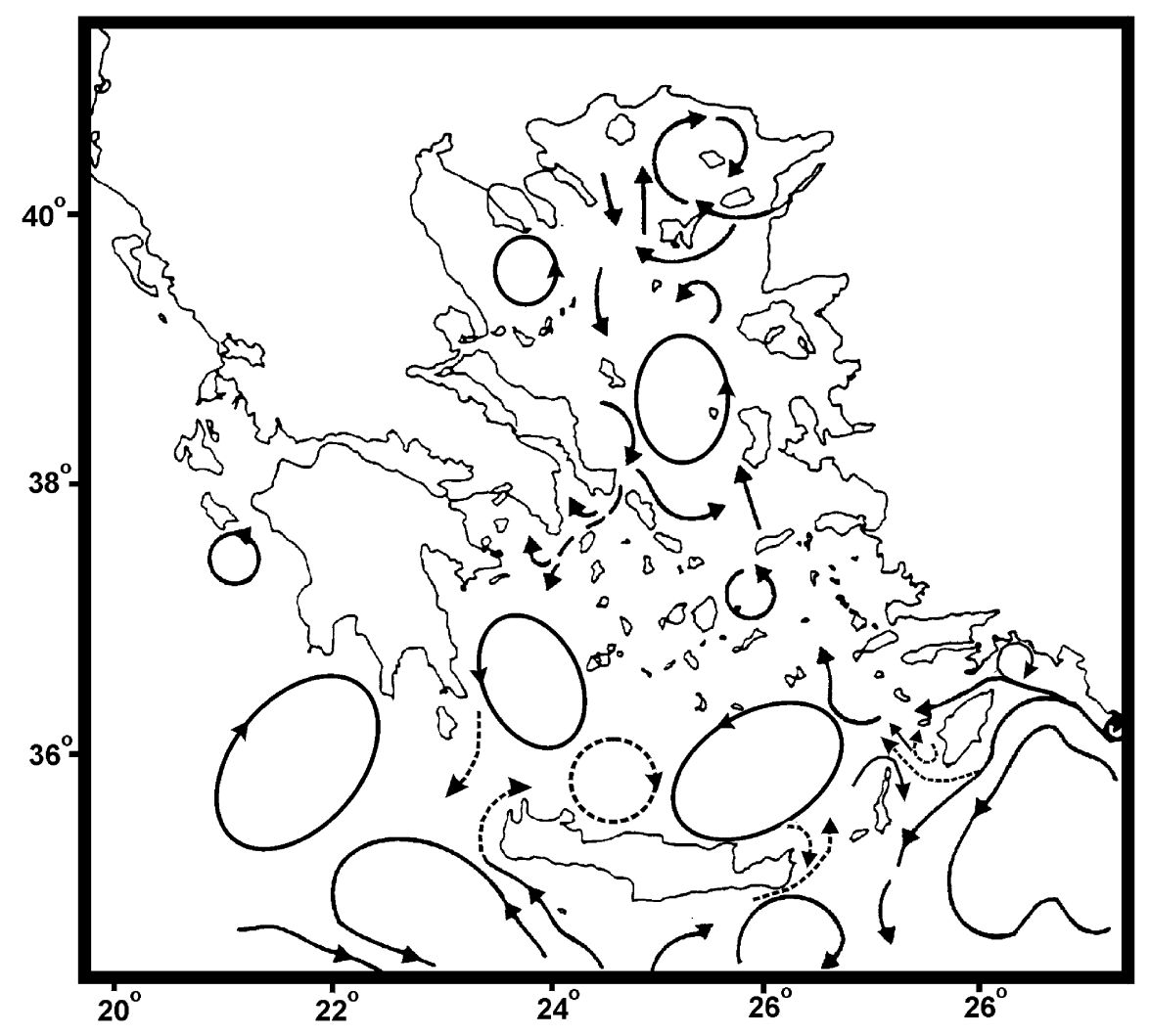

Fig. 3. Major upper thermohaline circulation features of the Aegean Sea (synthesis deemed from Theocharis et al., 1999a,b; Georgopoulos, 2001).

pides et al., 2000a,b; Van Wambeke et al., 2000). A review of all the relatively recent works relating to the Aegean has been given by Stergiou et al. (1977). Multidisciplinary and integrated biogeochemical studies have been carried out previously only in the S. Aegean, within the framework of the PELAGOS (MAST-I) and CINCS (MAST-II) projects. These projects either concentrated upon the chemical and water mass exchanges between the Cretan Straits (PELAGOS), or in the biochemical processes and pelagic/benthic coupling in the N. Cretan margin area (CINCS). The major results of these projects have been presented by Balopoulos and Collins (1999) and Tselepides and Polychronaki (2000). The MTP-IIMATER project $(1996-1999)$ is the first attempt to integrate the water column processes and benthic/ pelagic coupling of the entire Aegean ecosystem.
From the results of these projects, some processes have been elucidated and some parameters were assumed to play a key role in the biogeochemical processes, carbon cycle and energy transfer through the water column and sediments in the Aegean Sea. Among the controlling factors are: variability of the meso-scale circulation; deep water mass formation; the major river input; the Black Sea water inflow in the N. Aegean; the productivity changes in the euphotic zone; the bottom topography; and, probably, the aeolian input mainly in the form of dust.

The purpose of this paper is to summarise all the recent findings, including thermohaline circulation studies, SPM dynamics, mass and energy fluxes, biochemical processes in the euphotic layer and biogeochemical processes within the benthic layer (with particular reference to benthic response to downward 
fluxes) in a multidisciplinary and integrated approach. The major results in the Aegean Sea obtained within the framework of MTP-II-MATER (MAST-III) are compared to previously available information in order to better understand the functioning of such a complex system, which is crucial to the entire Mediterranean Sea.

\section{Methodology}

\subsection{Fieldwork}

The fieldwork was carried out using the oceanographic vessel R/V AEGAEO, during 1997-1998. Seasonal field studies were undertaken during (five) extensive cruises in March-April 1997, May 1997, February-April 1998, August-October 1998, and November 1998. A SBE-9 Plus Sea-Bird CTD profiler was used for data acquisition; this was equipped with pressure, temperature, conductivity, dissolved oxygen, fluorescence and light transmission sensors. The CTD profiler was mounted on a 24-Niskin-bottle rosette sampler to obtain water samples. The CTD salinity data were calibrated against water sample salinity, measured using an AUTOSAL salinometer. The CTD dissolved oxygen data were calibrated against values obtained with the Winkler volumetric titration method.

Fourteen sampling stations (Fig. 1) were selected carefully within major circulation features (gyresfronts), BSW influence, representative sub-basins in the North, Central and South Aegean, in order to investigate a more or less $\mathrm{N}-\mathrm{S}$ and $\mathrm{E}-\mathrm{W}$ gradients in the Aegean. At these stations, water samples were collected at standard depths for the analysis of chemical (nutrients, trace elements, POC, DOC) and biological parameters (chlorophyll- $a$, primary production, bacteria communities and production, microzooplankton communities). Mesozooplankton samples were collected at $0-50,50-100,100-200,200-300$, $300-500,500-700$, and $700-1000 \mathrm{~m}$ by a WP-2 net $(200 \mu \mathrm{m}$ mesh size). Among the sampling sites, five (identified as the most representative) were selected for "higher resolution" analysis of the mass fluxes with the deployment of sediment trap/current meter arrays, for a period of 12 months. Sediment traps (PPS/3 Technicup) and current meters (Aanderaa) were deployed at $500 \mathrm{~m}$ below the sea surface (bss) and $35 \mathrm{~m}$ above the sea bed (asb), at each mooring site. Benthic sampling was carried out by multiple corer and/or box cores, whilst in situ measurements were obtained by means of benthic lander deployments at the basic sampling stations (deployment period 36$48 \mathrm{~h})$.

\subsection{Laboratory analytical techniques}

Dissolved trace elements were measured using a Graphite Furnace Spectrophotometer (GFAAS-Perkin Elmer 4100-HGA 700-AS 70), after a preconcentration step (mercury was analysed by the cold vapor technique, with a Varian AA 20-plus spectrophotometer). Nutrients were analysed according to Strickland and Parsons (1977) standard methods, using a BranLuebbe Auto Analyser II. Total Organic Carbon (TOC) in seawater was analysed using a high-temperature catalytic oxidation (HTCO) SHIMADZU-5000 analyzer (Sempéré et al., 2002). Particulate Organic Carbon (POC), Nitrogen (PON), Phosphorus (POP) and Sulphur were analysed using a CHN analyzer (FISONS EA 1108) and a Perkin Elmer 2400. Thin film X-ray spectrometry and ICPMS were used for major the analysis of elements in the SPM and sediments. Bacterial production (BP) was measured by ${ }^{3} \mathrm{H}-$ leucine incorporation into proteins (Simon and Azam, 1989). Extracellular Proteolytic Activity (EPA) was measured using a Hitachi F-2000 spectrofluorometer (Hoppe, 1993). Sedimentary phytopigments were evaluated by spectroflurometric and HPLC methods adopted for the sediment-bound phytopigments (de Wilde et al., 1998). Abundance and biomass of benthic and planktonic bacteria and heterotrophic nanoflagellates were assessed by epifluorescence microscopy.

Samples for size fractionated $(0.2,1.2$ and $3.0 \mu \mathrm{m})$ chlorophyll- $a$ and primary production were collected from $1,5,10,20,30,40,50,75,100$ and $120 \mathrm{~m}$ depth. Chlorophyll- $a$ was analyzed using a TURNER 00-AU-10 fluorometer and primary production was measured with the in situ ${ }^{14} \mathrm{C}$ method. Quantitative and qualitative phytoplankton analysis was made using light microscopy (inverted microscope NIKON DIAPHOT). Underwater irradiance was measured with a LI COR 1800 Underwater spectroradiometer. Mesozooplankton biomass was estimated on the basis of dry-weight. Copepod production was estimated 
from biomasses and weight-specific egg production rates (Berggreen et al., 1988; Hopcroft et al., 1998); copepod grazing on phytoplankton was estimated by the gut fluorescence method (Mackas and Bohrer, 1976).

Carbohydrates were analysed using the method reported by Dubois et al. (1956). Protein analyses were carried out according to the technique desiccated by Hartree (1972). Lipid extraction was carried out according to Bligh and Dyer (1959). Their determination was performed using the method of Marsh and Weinstein (1966). The same methods were used for both suspended particle and trap material analyses. The analysis of the community structure of the various benthic components (bacteria, meiofauna, macrofauna and megafauna) was undertaken according to standard procedures; described thoroughly in recent papers (Danovaro et al., 2000a,b; Tselepides et al., 2000b; Kallianiotis et al., 2000).

\section{Results and discussion}

\subsection{Water mass formation processes and thermoha- line circulation}

The seasonal CTD field studies in the N. Aegean (winter 1997, winter-spring 1998, summer 1998, and November 1998) confirmed previous observations which suggested that the N. Aegean water column consisted essentially of three layers: low salinity waters with a high percentage of Black Sea Water (BSW), within the surface layer; highly saline and warm waters of Levantine origin (LIW) between 100 and $400 \mathrm{~m}$ depth; and very dense N. Aegean Deep water (NADW), within the bottom layer of each of the sub-basin.

The N. Aegean Sea is characterized by a generally cyclonic circulation. The most characteristic circulation feature in the N. Aegean is the front formed by the BSW discharged from the Dardanelles. These waters create a very shallow thermohaline front, less than $40 \mathrm{~m}$ thick, along their borders with the above-

Fig. 4. Surface water circulation in the N. Aegean, as expressed by the geostrophic currents at 5 dbar in May 1997 (a) and September 1998 (b).
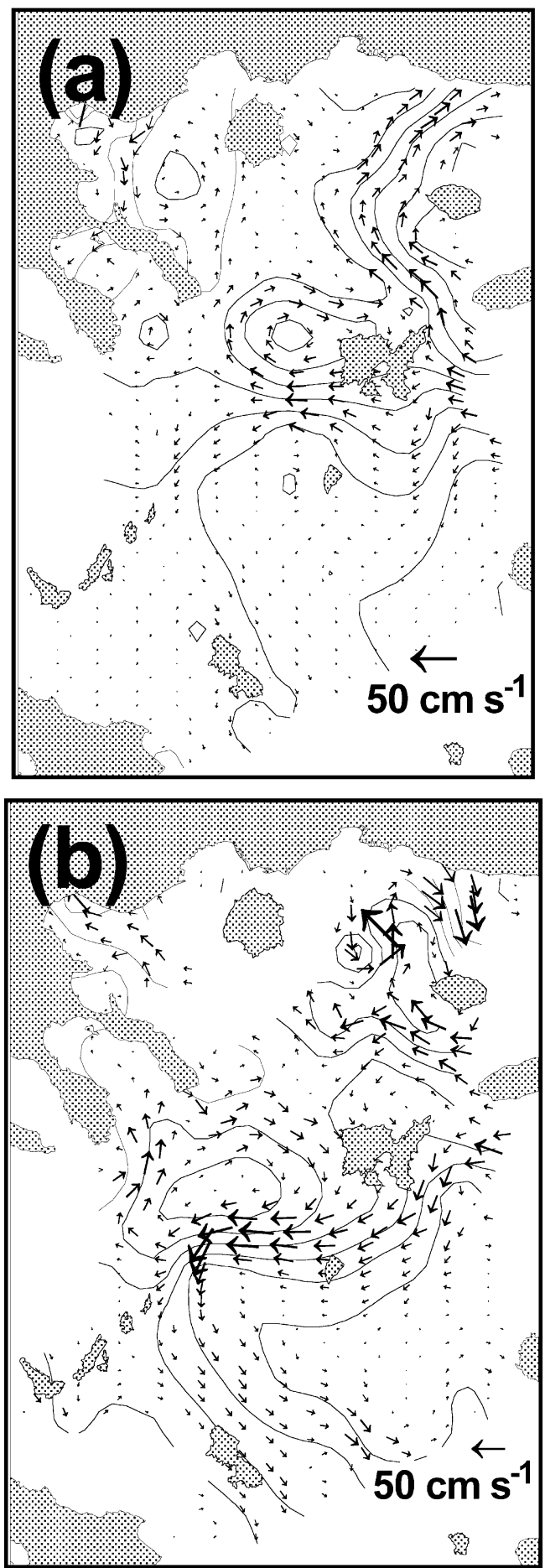
mentioned saline waters coming from the south (Fig. 4). Another mesoscale structure that appears to be a permanent feature of the region is a large anticyclone around the islands of Samothraki and Imvros (Georgopoulos, 2001). The layer between 100 and $400 \mathrm{~m}$ is occupied by waters of Levantine Intermediate waters (LIW). The LIW follows a general cyclonic route in the N. Aegean. Combined analysis of historical and recently gathered data suggests that the NADW is formed locally, at larger-than-annual intervals (Theocharis and Georgopoulos, 1993). The very dense water formation in the N. Aegean is controlled not only by air-sea interaction, but by the volume rate of Black Sea water outflow into the Mediterranean; thus, by the fresh water balance of the Black Sea. Two such incidents were identified in the late 1980s/early 1990s; these suggest that, possibly, the triggering of the transient of the Eastern Mediterranean took place also in the N. Aegean (Zervakis et al., 2000).

The data collected during the 1997-1998 surveys revealed important changes in the vertical distribution of the water characteristics in all the sub-basins of the S. Aegean, although the known and main features of the circulation persist. During this period, there is an enhanced presence in the upper layer of BSW, with strong intrusions of Modified Atlantic Water (MAW) occurring at both the eastern and western Cretan Straits. Below the surface, the upper $300 \mathrm{~m}$ layer is dominated by the saline Cretan Intermediate Water (CIW); this can be traced into the Ionian Sea. The Transitional Mediterranean Water (TMW) forms a distinct layer, below the CIW, characterised by a minimum in salinity and oxygen. The comparison of its hydrological characteristics between 1995 and 1997-1998 period shows that this water mass within the Cretan Sea has been largely transformed (Fig. 5); this is due mainly to mixing with the over and underlying waters, in the S. Aegean Sea. In particular, the signal of this water is very weak in the central part of the Cretan Sea, indicating also ventilation of the waters by advection down to $1500 \mathrm{~m}$. Below the TMW, the Cretan Deep Water (CDW) occupies a thick layer from $750 \mathrm{~m}$ depth to the seabed. Comparison with past data shows that the CDW has also been reduced and slightly modified, especially within its upper part $(750-1500 \mathrm{~m})$. The thermohaline changes are more pronounced in the western part of the S.

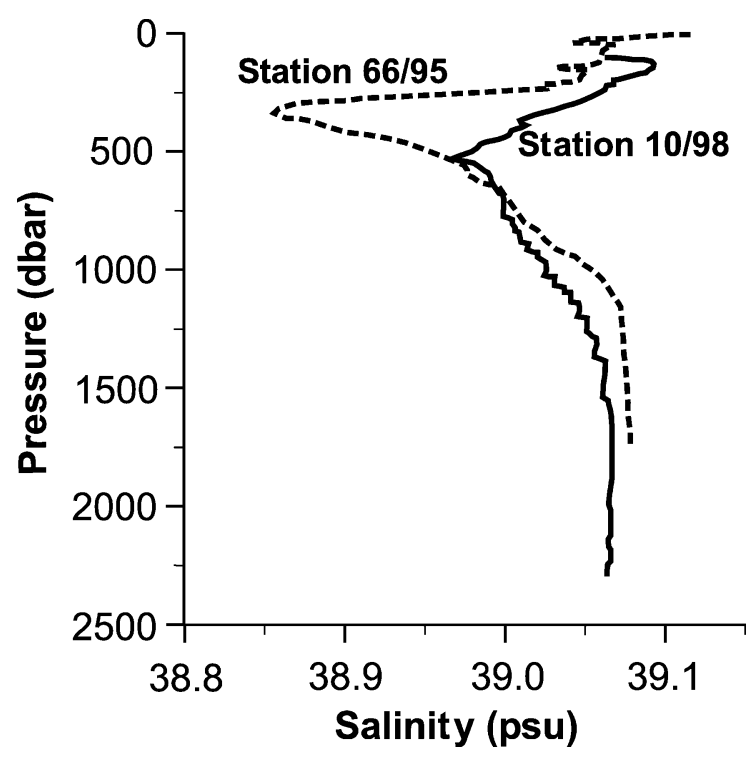

Fig. 5. Representative salinity profiles of the S. Aegean (East Cretan Sea) obtained during January 1995 (st.66/95) and October 1998 (st.10/98). Location of st.66/95 and st.10/98 in the proximity of MSB-7 (see Fig. 1).

Aegean, which first receives initially the signal of the newly formed waters. This pattern indicates that, after 1995, the water formed was probably not dense enough to sink to the deepest part of the S. Aegean. Instead, the observed newly formed water has intermediate characteristics (salinity $S>38.9-39.15 \mathrm{psu}$, but not very cold $\theta>15.0$ up to $15.6{ }^{\circ} \mathrm{C}$ ) with $\sigma \theta \sim 29.00-29.04$. The deeper parts of the Mirtoan and Cretan Sea (below 600-800 m) are occupied with very dense ( $\sigma \theta$ up to 29.35 ), but older water, which is the CDW formed during 1990-1995. The CDW volume inside the Cretan Sea has been reduced; this is due not only to the lack of dense water formation in recent years, but also to the continuous, although decreasing, outflow through the Cretan Straits to the Eastern Mediterranean during 1995-1998.

\subsection{Nutrients and oxygen}

The concentrations of nutrients, in terms of range of values and vertical distribution, are relatively similar in the N. and S. Aegean Sea (with a N/P ratio of 21). Within the euphotic zone $(0-100 \mathrm{~m})$, the nitrates range from $0.05-1.6 \mu \mathrm{M}$ in the North and from $0.05-1.6 \mu \mathrm{M}$ in the S. Aegean, with the phos- 
phate values varying from 0.02 to $0.08 \mu \mathrm{M}$ and from 0.02 to $0.06 \mu \mathrm{M}$, respectively. Nitrate and phosphate values in the euphotic layer of the BSW in the Sea of Marmara are slightly higher than in the Aegean (0.02-4.1 and 0.02-0.25 $\mu \mathrm{M}$, respectively) (CobanYildiz et al., 2000). However, important differences exist in the distribution and regeneration of nutrients within the deep water layers of the N. Aegean, where high oxygen consumption rates were observed. The comparative distribution of oxygen and nutrients in Limnos Basin (Stn MNB-1), in March, May and September 1997, shows a gradual mean decrease in oxygen $(0.1 \mu \mathrm{M})$ and an increase in nitrate $(0.5 \mu \mathrm{M})$, silicate $(1 \mu \mathrm{M})$ and phosphate $(0.02 \mu \mathrm{M})$ (Souvermezoglou et al., 1998); this is related to the different amounts and/or the chemical composition of the decomposed organic material (transported and sinking). The contribution of the BSW, with high concentrations of dissolved organic matter in the deep layers (through intermediate or deep water formation), must be significant. The distribution of oxygen and nutrients in the S. Aegean Sea is influenced by the exchange of water masses through the Cretan Straits; likewise, by the internal processes within the basin. Favourable weather and hydrographic conditions, for the development of the winter convective mixing, occur often; this has led to an increased oxygenation of the intermediate and deep layers of the Cretan Sea. During the winter of 1998, the vertical distribution of oxygen and nutrients showed homogenization down to the bottom in the Cyclades Plateau, which is in accordance with the intermediate water formation process that took place during this period. The "nutrient rich-oxygen poor" water masses of Transitional Mediterranean Water (TMW) are still present in the intermediate layers of the S. Aegean; however, their characteristics are less pronounced than those observed in 1994.

\subsection{SPM/DOC dynamics: particulate/dissolved trace metal exchange processes}

The configuration of the light transmission profiles in the N. Aegean Sea is different from that of the S. Aegean, reflecting clearly more "turbid waters"(light transmission values 80-94\%). With minor exceptions, the relatively high values of light transmission (low SPM) were measured in the N. Aegean during spring- (a)

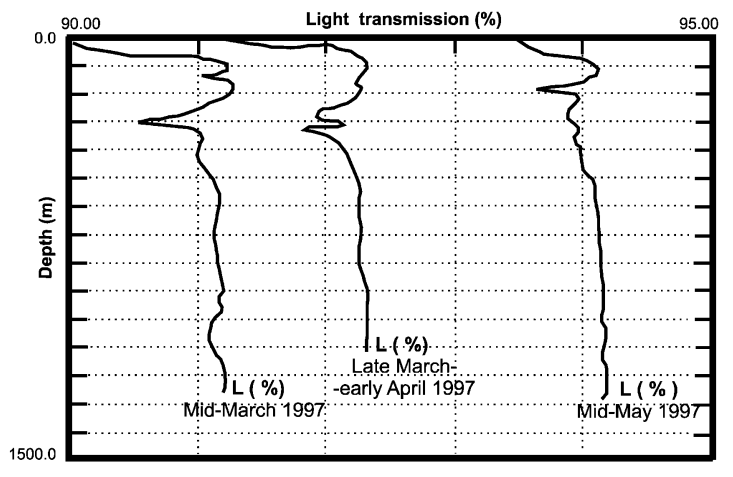

(b)

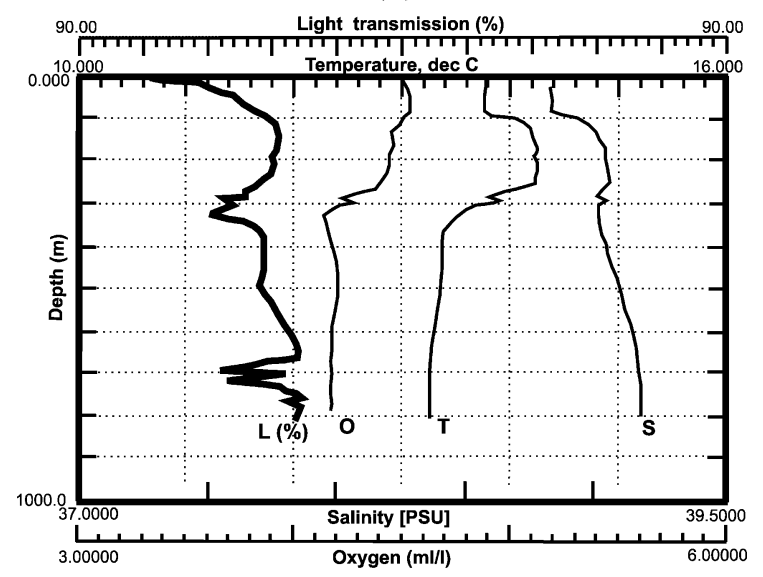

(c)

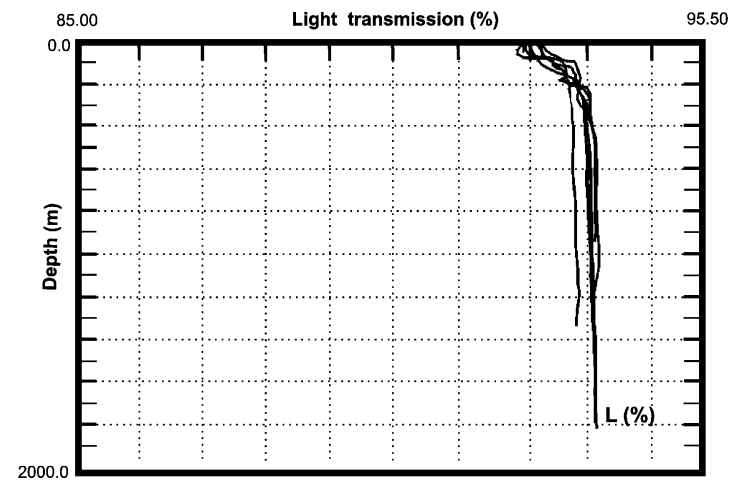

Fig. 6. Characteristic nepheloid layers obtained from the N. (a,b) and S. Aegean Sea (c). (a) Repeated light transmission profiles in the stn. MNB-1 during late winter-spring 1997. (b) Typical surface, intermediate and deep nepheloid layers from the stn. MNB-3 in comparison to the vertical profiles of the major hydrological parameters (salinity, temperature, oxygen). (c) Light transmission profiles from all the S. Aegean sampling stations during March 1997. For sampling station locations, see Fig. 1. 
autumn, and low values (high SPM) were observed during the winter period. The presence of weak intermediate nepheloid layers (INL) over the basins and pronounced bottom nepheloid layers (BNL) over the outer shelf-shelf break, with increased terrigenous load, is the characteristic "hydrosedimentary" feature of the N. Aegean Sea (Fig. 6).

The light transmission values in the S. Aegean appeared very high and relatively constant throughout the water column, ranging from $92 \%$ to $94 \%$ during the year. Consequently, the corresponding SPM values are estimated to be very low, in the order of about $0.2-0.3 \mathrm{mg} \mathrm{l}^{-1}$. There is no indication of intermediate or bottom nepheloid layers during the different sampling periods, although very weak nepheloid layers have been reported over the shelf break-upper slope of the N. Cretan margin (Chronis et al., 2000). The dynamics of SPM distribution in the S. Aegean is governed by the two-gyre system, which is a permanent feature over the Cretan Basin. The cyclone within the eastern part is associated with upwelling of relatively low SPM waters; the anticyclone, in the western part, cause downwelling of surface waters which have richer in SPM of biogenic origin (higher primary production).

No evident differences in the Particulate Organic Carbon (POC) concentrations were observed, when comparing the N. and S. Aegean waters. Particulate Organic Carbon values were highest within the euphotic zone and ranged between 40 and $140 \mu \mathrm{g}^{-1}$; while deeper than $200 \mathrm{~m}$, the respective values were appreciably lower and relatively constant, in their vertical distribution $\left(10-50 \mu \mathrm{g}^{-1}\right)$. In the N. Aegean Sea, higher POC values were observed at $200-500 \mathrm{~m}$ depth, in winter, and appeared to be related to the intermediate nepheloid layers. The values of Dissolved Organic Carbon (DOC) in the surface layer $(100 \mathrm{~m})$, expressed as Total Organic Carbon (TOC), ranged from 60 to $80 \mu \mathrm{M} \mathrm{C}$ in the S. Aegean and from 50 to $130 \mu \mathrm{M}$ $\mathrm{C}$ in the N. Aegean. This observation provides confirmation for the role of the inflow of Black Sea Water in providing dissolved carbon to the N. Aegean system benefits mainly heterotrophic bacteria (Sempéré et al., 2002, this issue). Persistent exposure of dissolved organic carbon, to solar radiation, has important consequences on DOM chemical composition and availability to bacterioplankton (Obernosterer et al., 1999, 2000). In waters deeper than $200 \mathrm{~m}$ in the Aegean, TOC values were relatively low, with a slight but constant decrease with depth (70-40 $\mu \mathrm{M} \mathrm{C})$.

Suspended POM (expressed as the sum of carbohydrate, protein and lipid contents) concentrations in the Aegean Sea were generally very low ranging from 23.2 to $161.6 \mu \mathrm{g}^{-1}$. Generally, POM concentrations in the N. Aegean were higher (up to double) than in the S. Aegean Sea (on average, 41.3 compared with $32.0 \mu \mathrm{g}^{-1}$ in summer, and 82.4 compared with 49.0 $\mu \mathrm{g} 1^{-1}$ in spring). The highest concentrations in the $\mathrm{N}$. Aegean were observed generally in spring, while in the $\mathrm{S}$. Aegean during the summer. Below $50 \mathrm{~m}$ depth, no clear seasonal or spatial changes were observed, indicating that most organic material produced in the surface water layers was promptly utilised. The analysis of the biochemical composition of the suspended POM revealed the dominance of proteins during summer (53-61\%, in S. and N. Aegean, respectively), followed by carbohydrates $(31-24 \%)$ and lipids (15\%, in both areas). However, in spring, the relative importance of carbohydrates and lipids increased in both N. and S. Aegean, with a consequent equal contribution of the three main biochemical components. Such changes in the biochemical composition, consistent with previous findings (Danovaro et al., 1999b), are linked clearly to the primary production

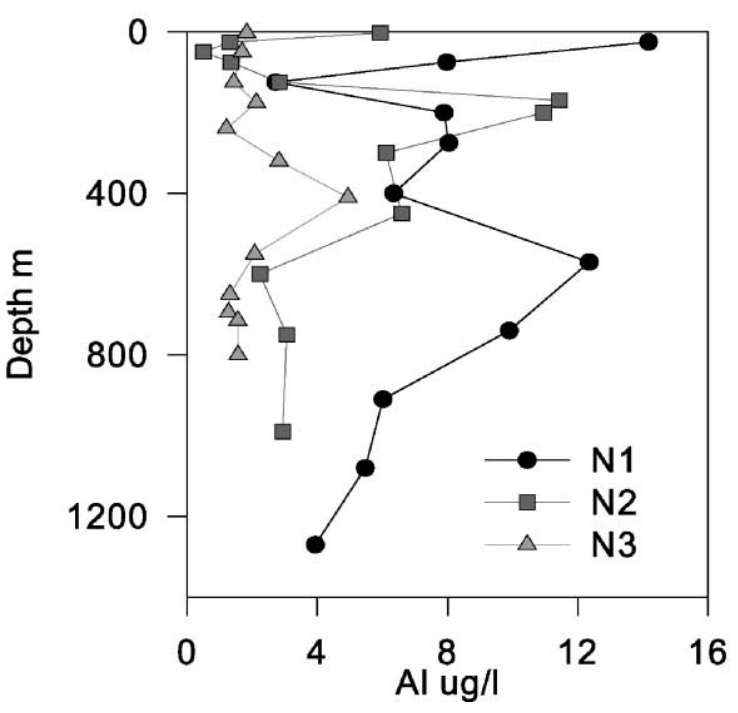

Fig. 7. Depth distributions of particulate $\mathrm{Al}$, at stations MNB-1 (N1), MNB-2 (N2) and MNB-3 (N3), in the N. Aegean during April 1998. 
cycles and are reflected in a reduction in the availability and nutritional quality of the suspended POM, from spring to summer.

Quantitative estimates of particulate terrigenous elements are best depicted from profiles of particulate Al (Fig. 7). Within the Cretan Sea, Al usually displayed concentrations ranging from 0.5 to $1.0 \mu \mathrm{g} \mathrm{l}^{-1}$, with highest concentrations at $200 \mathrm{~m}$ and at $600-800$ $m$ depth (Price et al., 1999). This pattern may indicate the presence of resuspended sediment at the shelf edge (Chronis et al., 2000) and on pycnoclines associated with the Cretan Deep Water. Substantially higher Al concentrations $\left(2-14 \mu \mathrm{g}^{-1}\right)$ were observed in the $\mathrm{N}$. Aegean and could be related to the resuspended nepheloid layers, especially at 200-250, 300-400 and $\sim 600 \mathrm{~m}$ depth.

In spring, $\mathrm{Fe} / \mathrm{Al}, \mathrm{Ti} / \mathrm{Al}$ and $\mathrm{Mg} / \mathrm{Al}$ ratios of 0.52 , 0.038 and 0.28 , respectively, were observed at all stations in the N. Aegean Sea. These data suggest that the presence of riverine resuspended sediment on the $\mathrm{N}$. Aegean shelf provide these signatures through the nepheloid layers. In contrast, in the S. Aegean, these ratios were considerably higher, but seasonally variable. This seasonal difference denotes probably differences in the aeolian inputs to the region. For instance, Ti enriched sediments characterise the Eastern Mediterranean and are assumed to be in dust of Saharan origin.

The results of particulate biogenous element concentrations in the S. Aegean show elevated concentrations within cyclonic eddies, where upwelling prevails (Price et al., 1999). Upwelling in spring 1997 promoted a high standing crop of diatoms, identified by particulate biogenic silica $\left(\mathrm{Si}_{\text {bio }}\right)$ concentrations of $\sim 10 \mu \mathrm{g}^{-1}$ which occurred in surface waters and at $150 \mathrm{~m}$, just below the chlorophyll- $a$ maximum (Fig. 8). The N. Aegean stations show, in late winter-early spring 1997 and 1998, high surface $(0-100 \mathrm{~m})$ particulate $\mathrm{P}$ concentrations $(0.2-0.65 \mu \mathrm{g} / \mathrm{l})$; these are similar to, or higher than, in the Cretan Sea $(0.2-$ 0.4 ) at stations associated with upwelling (MSB-1, MSB-2) but unusually low $\mathrm{Si}_{\text {bio }}\left(\sim 2 \mu \mathrm{g}^{-1}\right)$, suggest a
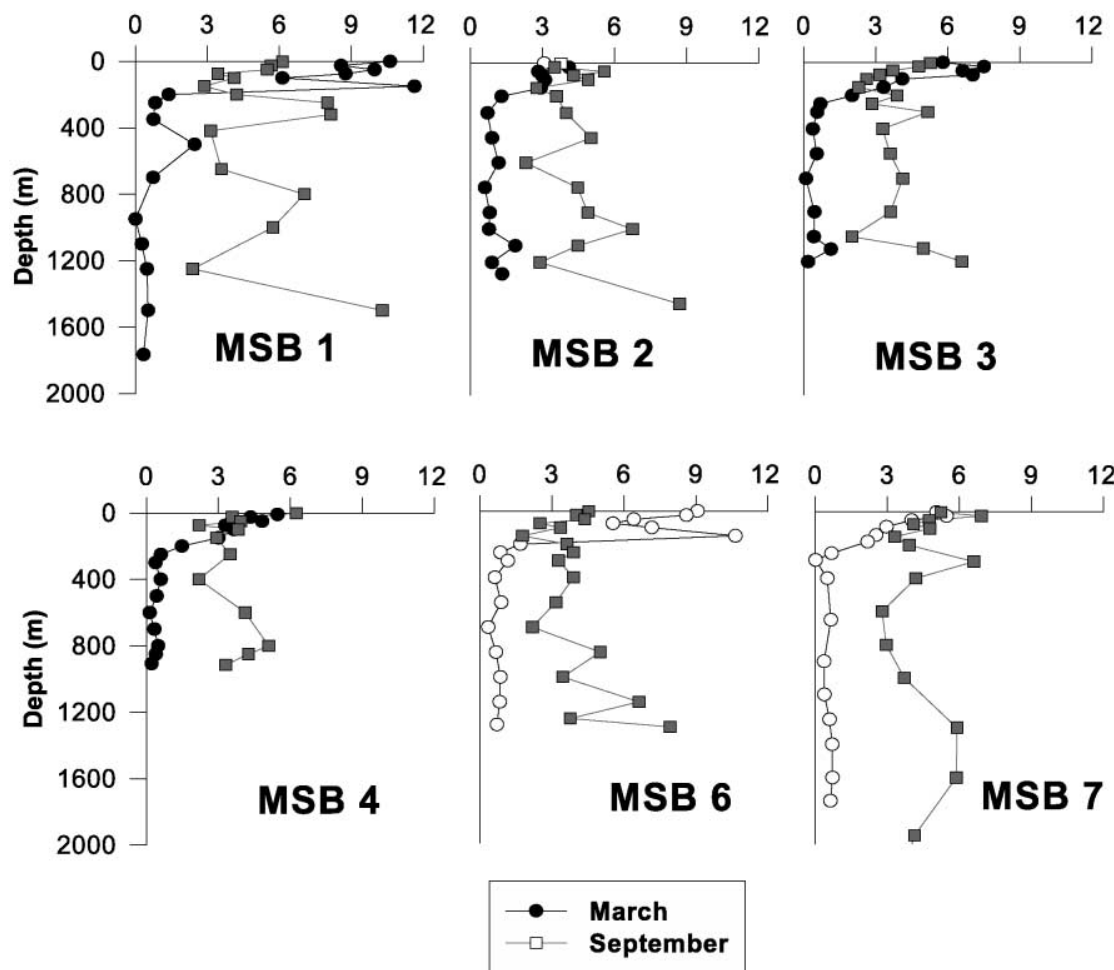

Fig. 8. Biogenic silica ( $\left.\mathrm{Si}_{\mathrm{bio}}\right)$ concentrations, with depth, for all the $\mathrm{S}$. Aegean Sea sampling locations. 
low standing crop of diatoms. $\mathrm{Si}_{\text {bio }}$ concentrations in September 1997 are substantially higher than in spring. In the Cretan Sea, in late summer, higher concentrations of mid- and deep water biogenous elements are considered to be a remnant of the fallout of the spring bloom; those in late winter-early spring could be results of a very limited biogenous fallout during and after the period of low water biological production. This observation is of considerable importance, as it suggests that fallout rates of SPM must be higher than generally realised, providing evidence that the whole water column can be "contaminated" within months by surface waters' production or any other input event.

Particulate trace metals $(\mathrm{Cu}, \mathrm{Zn}$ and $\mathrm{Pb})$ were studied, with respect to their inputs into the N. Aegean Sea, especially with regard to their introduction by terrigenous sediment fluxes from the N. Aegean shelf and their input to the basin from the Black Sea through the Dardanelles. In the S. Aegean, particulate trace metals were assessed, with respect to concentrations of biogenous constituents. The depth distribution of particulate excess of $\mathrm{Cu}, \mathrm{Pb}$ and $\mathrm{Zn}$ concentrations, over that associated with terrigenous aluminosilicates in the $\mathrm{S}$. Aegean, shows a similarity with the major biogenic elements, especially $\mathrm{Si}_{\text {bio }}$ and $\mathrm{P}_{\text {org }}$; this implies that these elements are likely to be bound to biogenic substances. Seasonal contrasts in the excess $\mathrm{Pb}$ concentrations in the N. Aegean must be related to the high level of resuspension of the metals from the northern shelf. This is related, probably, to fishing (trawling) activity during October-May (Lykousis, 1998).

Input of Black Sea Water through the Dardanelles is much more evident in late summer than in winter. This input can be identified from a much lower salinity, i.e. 33-36 psu over the N. Aegean Trough, extending down $\sim 30 \mathrm{~m}$ below the surface. No high surface concentrations of excess particulate metals occur within these waters in late summer; this implies that, if there is metal discharge through the Dardanelles, it occurs mostly in the dissolved phase.

Dissolved trace element concentrations are generally higher in the $\mathrm{N}$. than in the S. Aegean at the corresponding depths. Cadmium, $\mathrm{Cu}$ and $\mathrm{Ni}$ distributions are quite uniform in the entire water column and only minor variations (slightly enhanced values) are observed in the upper layer of certain N. Aegean stations. These relatively high concentrations prob- ably indicate that $\mathrm{Cd}, \mathrm{Cu}$ and $\mathrm{Ni}$ have common sources in the area, i.e. atmospheric deposition, coastal runoff and influence of Black Sea Water (Voutsinou-Taliadouri et al., 1999). Slightly increased levels of $\mathrm{Cu}(2-4 \mathrm{nM})$ were found within intermediate layers of the N. Sporades Basin (MNB-3). Furthermore, in this area and below the depth of $500 \mathrm{~m}$, there is some evidence of a further concentration increase, probably due to, either to the downward transport of biological particles with a subsequent release during particle breakdown, or to $\mathrm{Cu}$ remobilization at the sediment-water interface through resuspension. The concentrations of $\mathrm{Cd}, \mathrm{Cu}$ and $\mathrm{Ni}$ in the S. Aegean reveal almost constant values throughout the watercolumn similar to those observed in the N. Aegean below the depth of $100 \mathrm{~m}$ (Voutsinou-Taliadouri et al., 2000).

The scavenged character of $\mathrm{Mn}$ was pronounced at all the stations of the N. Aegean, with elevated surface values down to about $100 \mathrm{~m}$ depth, a rapid decrease in the intermediate layer and then an increase with depth, probably due to Mn remobilization from sediments. Surface values $(44.98 \mathrm{nM})$ of one order of magnitude higher than those of the intermediate and bottom layers $(4.80 \mathrm{nM})$ were recorded, especially during September (period of increased BSW inflow), suggesting the influence of Black Sea Water that is enriched with Mn (Zeri et al., 2000). Manganese values in the S. Aegean are considerably lower compared with N. Aegean ones, showing relatively enhanced surface values which decrease with depth. Atmospheric inputs and/or dissolution of Mn hydroxides from particles due to photochemical processes (Sunda et al., 1983) may probably explain these enrichments.

\subsection{Production in the photic zone-food web}

Fractionated chlorophyll- $a$ and photosynthetic productivity (in situ ${ }^{14} \mathrm{C}$ method) data in $\mathrm{N}$. and $\mathrm{S}$. Aegean Sea are given in Table 1. Most of the biomass $(49-56 \%)$ and the photosynthetic activity $(41-51 \%)$ was due to the picoplankton fraction $(0.2-1.2 \mu \mathrm{m})$, while the nano+microplankton fraction $(>3.0 \mu \mathrm{m})$ contributed to the $21-31 \%$ of chlorophyll- $a$ and the $20-33 \%$ of primary production. The ultraplankton fraction $(1.2-3.0 \mu \mathrm{m})$ accounted for the $18-23 \%$ of the total chlorophyll- $a$ and primary production. The estimated annual production was $29.8 \mathrm{~g} \mathrm{C} \mathrm{m}^{-2}$ year $^{-1}$ 
Table 1

Overall integrated means of chlorophyll- $a$ and primary production fractions in N. and S. Aegean Sea

\begin{tabular}{|c|c|c|}
\hline Parameter & $\begin{array}{l}\text { Chlorophyll- } a \\
\left(\mathrm{mg} \mathrm{m}^{-2}\right)\end{array}$ & $\begin{array}{l}\text { Primary production } \\
\left(\mathrm{mg} \mathrm{C} \mathrm{m}^{-2} \mathrm{~h}^{-1}\right)\end{array}$ \\
\hline Fractions & Range (mean) & Range (mean) \\
\hline \multicolumn{3}{|c|}{ North Aegean Sea } \\
\hline $0.2-1.2(\mu \mathrm{m})$ & $6.41-32.93(18.67)$ & $7.09-133.92(34.58)$ \\
\hline $1.2-3.0(\mu \mathrm{m})$ & $3.18-10.54(6.54)$ & $2.71-63.96(13.66)$ \\
\hline$>3.0(\mu \mathrm{m})$ & $4.18-12.81(7.87)$ & $4.91-53.74(19.51)$ \\
\hline Total & $18.76-50.67(33.21)$ & $14.71-251.62(67.95)$ \\
\hline \multicolumn{3}{|c|}{ South Aegean Sea } \\
\hline $0.2-1.2(\mu \mathrm{m})$ & $6.71-25.41(12.22)$ & $5.87-18.86(10.56)$ \\
\hline $1.2-3.0(\mu \mathrm{m})$ & $2.58-10.63(5.69)$ & $1.37-23.15(8.04)$ \\
\hline$>3.0(\mu \mathrm{m})$ & $3.51-17.77(8.66)$ & $5.12-31.61(12.74)$ \\
\hline Total & $17.35-45.76(26.58)$ & $12.36-62.63(31.34)$ \\
\hline
\end{tabular}

in N. Aegean and $15.2 \mathrm{~g} \mathrm{C} \mathrm{m}^{-2}$ year $^{-1}$ in S. Aegean Sea. Cell abundances measured by light microscopy (overall means over depth and station and season) were $5.6 \times 10^{3}$ cells $1^{-1}$ in the N. Aegean and $1.9 \times 10^{4}$ cells $1^{-1}$ in the S. Aegean. The depth of the euphotic zone $\mathrm{Z}_{(1 \%)}$ in $\mathrm{N}$. Aegean varied between 100 and $80 \mathrm{~m}$ and from 147 to $110 \mathrm{~m}$ in the S. Aegean (autumn 1997 and spring 1998, respectively). These data demonstrate that, although the production levels in the $\mathrm{N}$. Aegean are somehow higher in relation to those in the S. Aegean, the entire Aegean can be classified as highly oligotrophic.

Heterotrophic bacterial growth was studied in the sample period undertaken in March and September 1997. Surface values (5 m depth) of bacterial production were 2 to 3 times higher in the N. Aegean stations, influenced by the input of the Black Sea Waters. Outside the influence of Black Sea Water, mean bacterial numbers in the $0-100 \mathrm{~m}$ layer showed typical oceanic concentrations, averaging $0.7 \times 10^{6}$ cells $\mathrm{ml}^{-1}$. These values, together with low bacterial production rates $\left(30 \mathrm{ng} \mathrm{C1^{-1 }} \mathrm{h}^{-1}\right.$ ), implied slow growth for bacteria and/or that a large number among them were inactive. Integrated bacterial production rates ranged from 17 to $164 \mathrm{mg} \mathrm{C} \mathrm{m}^{-2}$ day $^{-2}$, with higher values associated with areas under the influence of Black Sea Waters (Fig. 9). Enrichment experiments confirmed P-limitation for bacterial production, while there were also indications of better utilization of DOC by bacteria after addition of phosphate. Bacterivory appeared to be dominated by heterotro- phic, rather than mixotrophic, nanoflagellates. Estimated nanoflagellate bacterivory accounted for $40-$ $100 \%$ of bacterial production, with mixotrophic nanoflagellates consuming only $5 \%$ of bacterial production (Christaki et al., 1999).

Generally, distinct differences in the community structure of attached and free-living bacteria, defined as operational taxonomic units, were found in mesopelagic waters ( $>200 \mathrm{~m} \mathrm{depth})$, as compared to the upper mixed water column ( $\approx 10-200 \mathrm{~m})$. Data on the distribution of free-living, compared with attached, bacteria suggest that even in the absence of temperature as a selecting factor for bacteria in the deep water layers, there is a distinct deep-water community present; this is characteristic particularly of the freeliving life mode, adapted to exploit the refractory dissolved organic matter pool. This free-living bacterial community appears to be as complex as the surface water bacterial community (Moeseneder et al., 2001).

The quantitative characteristics of the ciliate community, especially during September, are at a lower range $\left(0-780\right.$ cells $\left.1^{-1}\right)$ than values reported from other ocean regions (Pitta and Giannakourou, 2000). The outflow of the Black Sea Water resulted in the dominance of mixotrophic species, of 18 to $30 \mu \mathrm{m}$; to the south, as well as at the remaining of the northern stations, nanosilicates were the major mixotrophic size class. S. Aegean stations presented more diverse ciliate fauna, with a uniform distribution down to 100 $\mathrm{m}$ and higher values of integrated abundance and biomass, than in the N. Aegean. Since primary pro-

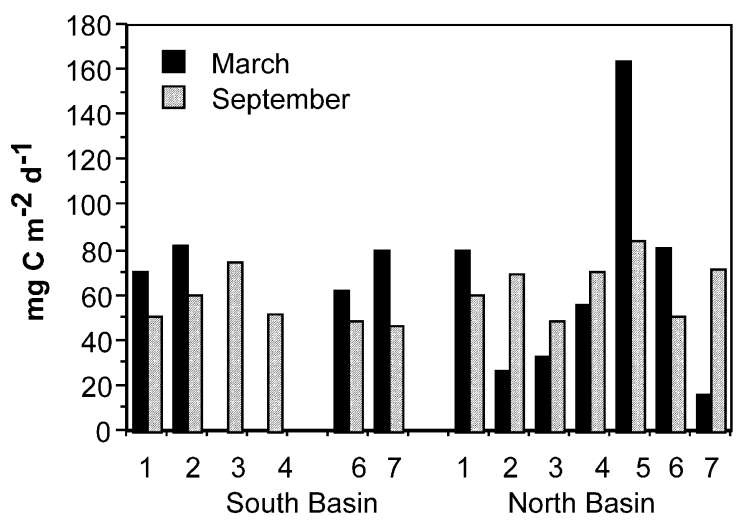

Fig. 9. Integrated bacterial production, during two contrasting seasons (March and September, 1997), for the North and S. Aegean. 
duction is higher at the NE Aegean stations, the general impoverishment in ciliates there could be attributed to a strong "top-down" regulation by mesozooplankton grazers (Pitta and Giannakourou, 2000). The heterotrophs/autotrophs biomass and the bacterial production to primary production ratio (Siokou-Frangou et al., 2002, this issue) imply a gradual increasing contribution of the biomass of heterotrophs and grazing, through the microbial food web, from the $\mathrm{NE}$ Aegean to the S. Aegean. It is clear that microheterotrophs (bacteria+nanoflagellates+ciliates) play an important role within the planktonic food web of the Aegean Sea and this role becomes more significant gradually from NE Aegean towards S. Aegean during the stratification period.

Mesozooplankton abundance and biomass were both higher in the North relative to the S. Aegean (mean of March and September, 1997: 2283 compared with 654 ind $\mathrm{m}^{-3}$, for the $0-50 \mathrm{~m}$ layer) reflecting the very oligotrophic character of the $\mathrm{S}$. Aegean. This pattern was especially pronounced during March 1997 in the upper layer (BSW influenced) of the stations located close to the Dardanelles Straits (MNB4 and MNB5). A decrease with depth of these

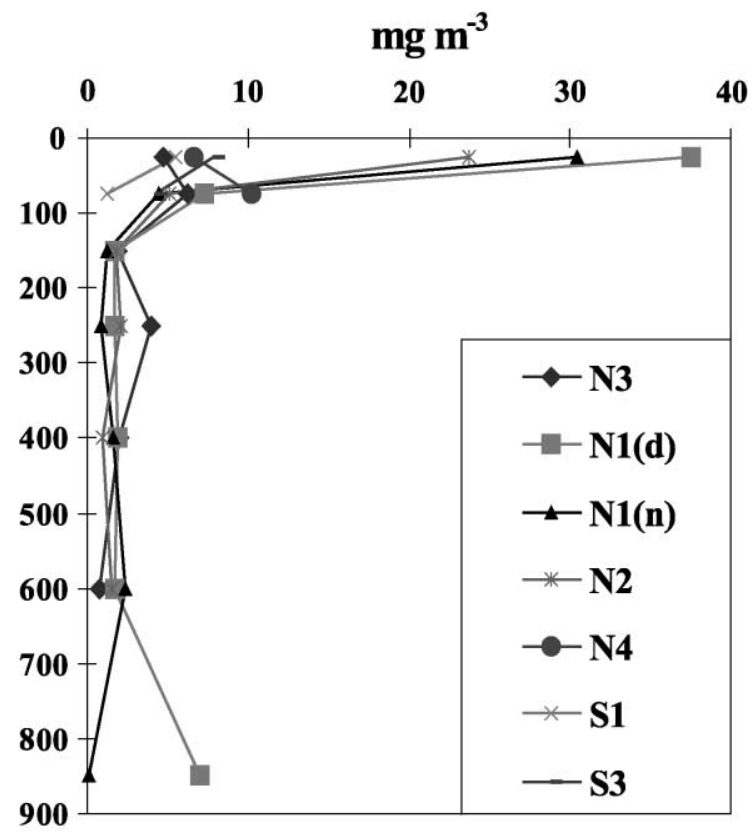

Fig. 10. Vertical distribution of zooplankton biomass, during March 1998. parameters followed the same pattern (Fig. 10), suggesting that higher amounts of organic matter are available in the deep layers of the N. relatively to $\mathrm{S}$. Aegean. Species composition was differentiated between areas, mainly regarding the uppermost $(0-$ $50 \mathrm{~m})$ and the deepest $(500-1000 \mathrm{~m})$ layer. Stations positioned close to the Dardanelles Straits were distinguished from the "normal" Aegean stations, both quantitatively and qualitatively; this is probably due to the influence of the Black Sea water masses.

The grazing pressure of copepods on primary production, during March 1997, was found to be very low in the N. Aegean, when compared to the S. Aegean, where the grazing pressure was more important in September. Copepod production was higher in the NE Aegean and it decreased towards the S Aegean. It seems that copepods benefit more from the available food in the NE Aegean, than in the rest of the N. Aegean and the S. Aegean. In addition, the important abundance of cladocerans and appendicularians in the N. Aegean during September, which are organisms able to exploit the available small autotrophs and heterotrophs in the area, indicates more efficient trophic relationships within the food web. Therefore, it seems that in the N. Aegean, the trophic food web is more complex than in the S. Aegean and mesozooplankters can profit even from the lower levels of the food web (Siokou-Frangou et al., 2002). All the above observations (importance of microheterotrophs, grazing pressure on ciliates and phytoplankton) suggest that a microbial food web has been developed in the N. Aegean and a multivorous food web in the S. Aegean Sea. It has been estimated that there is a greater availability of the smaller autotrophs to microzooplankton carbon demand in the North than in the S. Aegean Sea. This observation, in combination with the observed lower grazing pressure of copepods on phytoplankton, suggests that there will be a greater export of primary production from the euphotic zone in the $\mathrm{N}$. Aegean than in the S. Aegean.

\subsection{Quantification of downward fluxes and charac- terisation of settling particles}

The strong contrast in mass flux registered between the $\mathrm{N}$. and the S. Aegean confirms the southern trend towards an oligotrophy gradient in the NE Mediterranean (Fig. 11). In general, downward mean annual 


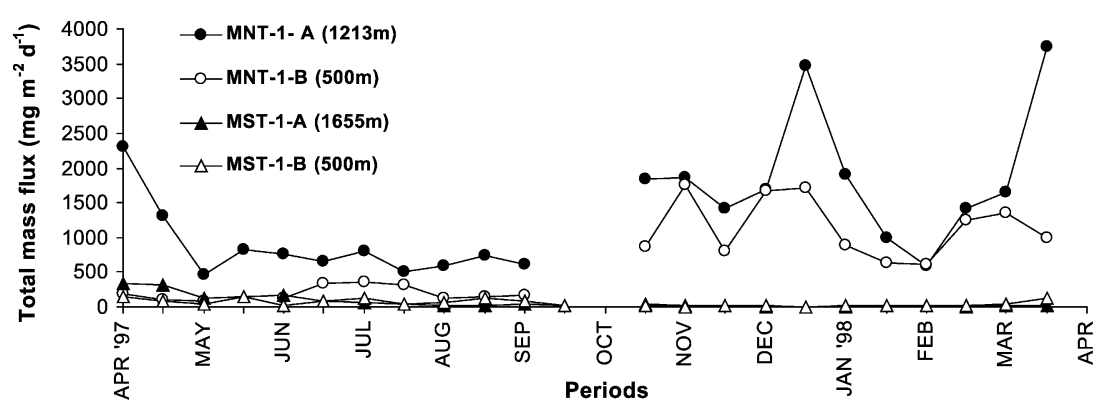

Fig. 11. Total mass fluxes in the Aegean Sea during April 1997-April 1998; for station locations see Fig. 1.

masses flux tend to decrease gradually, from north to south at $35 \mathrm{~m}$ asb level (Table 2). Mass fluxes increased with depth by almost the same order at each location. The highest mass fluxes were observed in winter, whilst mass fluxes in the S. Aegean were higher during summer (taking into account that, at the southern sites, the lithogenic flux decreased from early summer to winter). This pattern implies that much of the lithogenic material is of aeolian origin in the S. Aegean, suggesting a significant contribution of resuspension and/or aeolian dust originated from the Saharan desert, during the strong SW winds in April-May.

The N. Aegean mass fluxes are characterised strongly by the lithogenic constituent, due to the river discharge from the northern mainland of Greece. In contrast, the S. Aegean fluxes appear to depend more upon the biogenic (organic and inorganic carbon, opal) component and less on the lithogenic fall-out. In the S. Aegean, the organic matter fluxes decrease with depth and contrast with the increase of mass flux with depth; this is in response to the organic carbon reaching the deep water and, finally, the benthos ( $35 \mathrm{~m}$ asb), which was less than that measured at $500 \mathrm{~m}$ bss. This characteristic implies that organic matter produced within the shallow waters was decomposed progressively and/or remineralised by the biogeochemical (microbial) processes. Thus, only a very small fraction of the initial amount reaches the bottom (i.e. an "oceanic margin" environment). In contrast, the N. Aegean can be termed a "continental margin", dominated by increases in the organic carbon flux, with depth, accompanied by a significant terrigenous inorganic component. The limited inorganic carbon flux in the N. Aegean, compared with the South and the similar opal fluxes, can be attributed to differences in the phytoplankton community structures in the two areas (i.e. more coccoliths in S. than in the N. Aegean).

The higher fluxes of labile Particulate Organic Carbon (POC) in the N. Aegean Sea, relative to the South, are due to the greater export of primary production from the euphotic zone in the N. than in the S. Aegean (Siokou-Frangou et al., 2002). The vertical carbon export in the N. Aegean Sea comprises an admixture of plankton cell and feacal pellet carbon, to depths of $>1500 \mathrm{~m}$; this implies a rapid and close relationship between benthic/pelagic coupling. The

Table 2

Mean annual downward mass fluxes in the N. and S. Aegean Sea (April 1997-April 1998)

\begin{tabular}{|c|c|c|c|c|c|c|}
\hline & \multicolumn{3}{|l|}{$500 \mathrm{~m}$} & \multicolumn{3}{|l|}{$35 \mathrm{mab}$} \\
\hline & $\begin{array}{l}\text { Mean annual } \\
\text { total mass fluxes } \\
\left(\mathrm{mg} \mathrm{m}^{-2} \text { day }^{-1}\right)\end{array}$ & $\begin{array}{l}\text { Mean fluxes } \\
\text { of Labile } \mathrm{OM}^{\mathrm{a}} \\
\left(\mathrm{mg} \mathrm{m}^{-2} \mathrm{day}^{-1}\right)\end{array}$ & $\begin{array}{l}\text { Mean annual } \\
\text { lithogenic fluxes } \\
\left(\mathrm{mg} \mathrm{m}^{-2} \text { day }^{-1}\right)\end{array}$ & $\begin{array}{l}\text { Mean annual } \\
\text { total mass fluxes } \\
\left(\mathrm{mg} \mathrm{m}^{-2} \text { day }^{-1}\right)\end{array}$ & $\begin{array}{l}\text { Mean fluxes } \\
\text { of Labile } \mathrm{OM}^{\mathrm{a}} \\
\left(\mathrm{mg} \mathrm{m}^{-2} \mathrm{day}^{-1}\right)\end{array}$ & $\begin{array}{l}\text { Mean annual } \\
\text { lithogenic fluxes } \\
\left(\mathrm{mg} \mathrm{m}^{-2} \text { day }^{-1}\right)\end{array}$ \\
\hline MNB-1 & 690.2 & - & 494.4 & 1379.4 & - & 990.8 \\
\hline MNB-2 & - & - & - & 508.1 & 226.9 & 337.2 \\
\hline MNB-3 & 353.5 & 98.4 & 179.1 & 514.3 & - & 276.2 \\
\hline MSB-1 & 57.7 & 15.4 & 25.5 & 67.9 & 23.5 & 30.7 \\
\hline MSB-2 & 67.7 & - & 28.1 & 94.9 & 29.5 & 40.2 \\
\hline
\end{tabular}

${ }^{\text {a }}$ Average values only for the period April-June 1997. 
flux of Labile Organic Matter (LOM, considered as the sum of carbohydrates, proteins and lipids) within the $500 \mathrm{~m}$ traps was $2-5$ times higher in the North relative to the S. Aegean, with the highest average value (April-June 1997) occurring at Stn MNB-3 (98.4 mg $\mathrm{m}^{-2}$ day $^{-1}$ ) and the lowest at the Stn MSB-1 (15.4 mg $\mathrm{m}^{-2}$ day $^{-1}$ ) (Table 2). In the bottom traps (35 m asb), the higher average flux of LOM (April-June 1997) were recorded at Stn MNB-1 (226.9 $\mathrm{mg} \mathrm{m}^{-2}$ day $^{-1}$ ) and the lower at Stn MSB-1 and MSB-2 (23.5 and 29.5 $\mathrm{mg} \mathrm{m}^{-2}$ day $^{-1}$ ). The near-bottom fluxes of LOM in the N. Aegean were about 9-10 times higher than those recorded in the S. Aegean, implying significant lateral deep fluxes of LOM in the isolated north basins. Total carbohydrates were the dominant biochemical class of LOM, accounting for about $70-85 \%$ the total mass flux of LOM in all the traps of the N. and S. Aegean. The dominance of carbohydrates in the trap material contrast with the protein dominance in suspended POM, suggesting that proteins are rapidly hydrolysed and consumed during their descent.

\subsection{Benthic response to downward fluxes}

The N. Aegean exhibits higher sediment loads of organic carbon (mean $0.712 \%$ ) relative to the $\mathrm{S}$. Aegean (mean $0.341 \%$ ) and also higher concentra- tions of lithogenic elements ( $\mathrm{Li}, \mathrm{Ti}, \mathrm{Sc})$ and slightly elevated concentrations of heavy metals (such as V, $\mathrm{Cr}, \mathrm{Ni}, \mathrm{Zn}$, and $\mathrm{Pb}$ ). Mean chlorophyll- $a$ concentrations within the uppermost $0-3 \mathrm{~mm}$ sediment layer in the $\mathrm{N}$. Aegean ranged from 0.156 to $0.585 \mu \mathrm{g} \mathrm{g}^{-1}$ while in the S. Aegean did not exceed $0.2 \mu \mathrm{g} \mathrm{g}^{-1}$ (Fig. 12), with the exception of the deep-basin station $\mathrm{S} 1$ (MSB1) (chlorophyll- $a$ levels $0.333 \mu \mathrm{g} \mathrm{g}^{-1}$ ). In general, inputs of fresh phytodetrital material, to the bottom sediments of the N. Aegean, were double those accumulating in the S. Aegean.

Among the labile organic components, carbohydrates, the main biochemical component, were about 1.2 times higher in the South than in the N. Aegean, but did not display significant temporal variability (4.7-6.0 and 5.0-5.9 $\mathrm{mg} \mathrm{g}^{-1}$ in the South and N. Aegean, respectively). Total proteins displayed significant temporal variations, with spatial differences being higher in summer $\left(2.49-4.20 \mathrm{mg} \mathrm{g}^{-1}\right.$ in the North compared with $1.33-2.67 \mathrm{mg} \mathrm{g}^{-1}$ in the $\mathrm{S}$. Aegean). The temporal patterns reported indicate that proteins are more dependent upon phytopigment accumulation, rather than on the protein input from particle rain. Organic matter $(\mathrm{OM})$ was characterised by a large fraction of soluble compounds $(14-32 \%$ of protein; $11-26 \%$ of the total lipid; and $0.8-4.3 \%$ of total carbohydrate concentrations) indicating that the

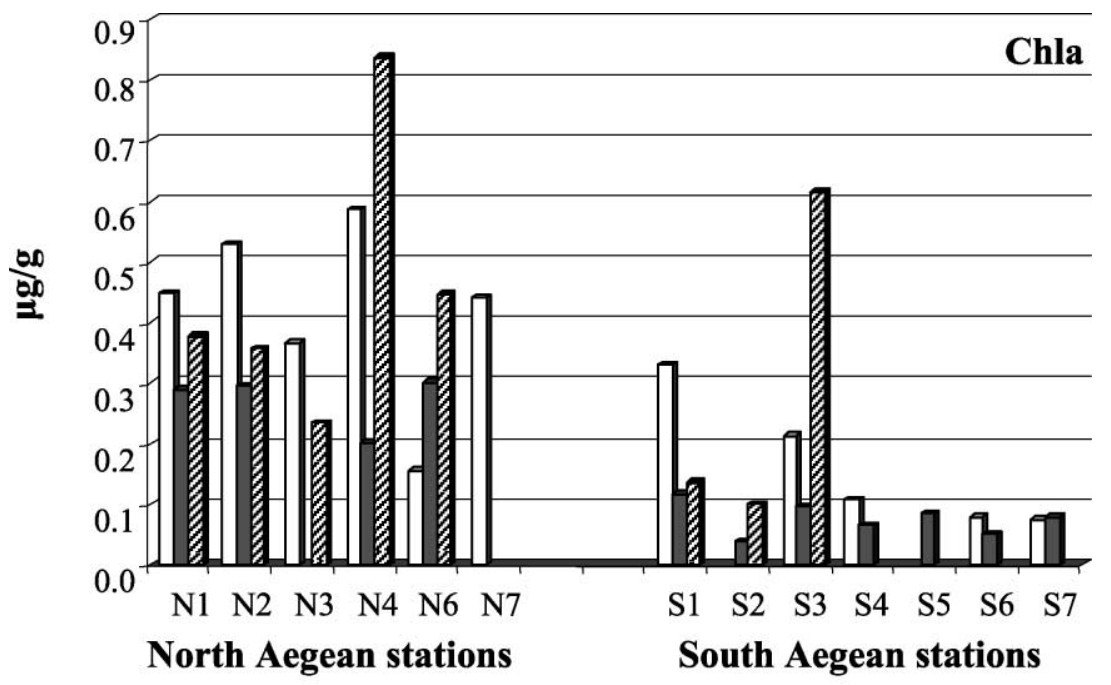

口MARCH '97 घSEPTEMBER '97 @MARCH '98

Fig. 12. Temporal variation of mean chlorophyll- $a$, within the $0-3 \mathrm{~mm}$ sediment layer, at N. and S. Aegean stations. 
quality of OM was better in the N. Aegean. Similar biopolymeric carbon concentrations within the two areas suggest that differences in OM quality in the Aegean Basin are dependant upon system productivity, whereas the bulk of the total organic pool is largely conservative (Danovaro et al., 1999c,d). This interpretation confirms previous findings on the low nutritional quality of the sedimentary OM in the deep eastern Mediterranean (Danovaro et al., 1993). Depth was correlated negatively with pigment concentrations, indicating that significant mineralisation of phytodetrital material takes place before it settles to the sediment surface. However, organic carbon and nitrogen content, as well as the $\mathrm{C}: \mathrm{N}$ ratio, did not correlate highly with depth, thus supporting the observed trend of higher OM levels within the isolated deep basins. The surprisingly high organic content of the deep stations provides evidence for the accumulation of OM. This could be attributed either to decreased biological processing or topographic features that induce (through near bottom currents) the transfer of OM to the deeper parts of the basin.

Bacterial density in the sediments was about double in the N. Aegean than on the S. Aegean Sea (4.2 compared with $2.4 \times 10^{8}$ cells $\mathrm{g}^{-1}$, respectively), and

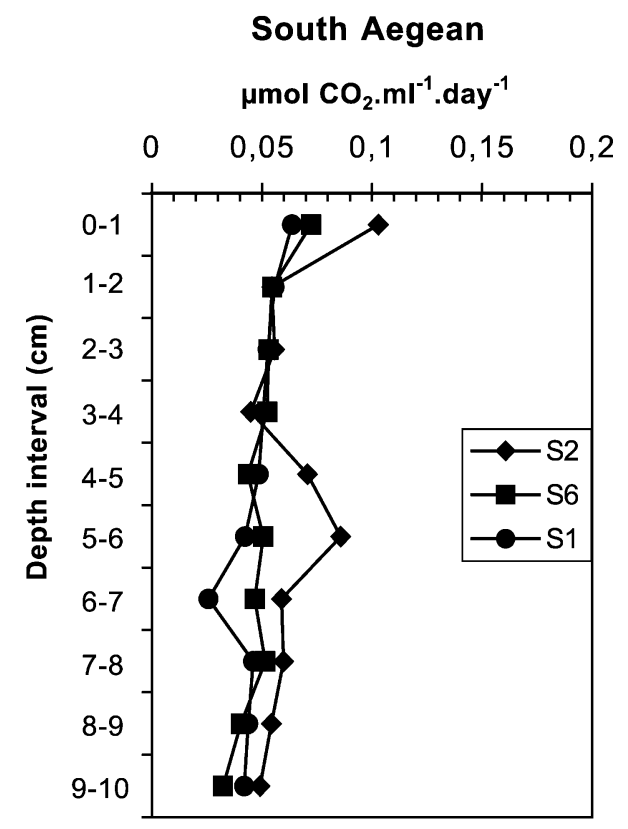

higher in March-April than in September. Bacterial size was about three-fold larger in September, so that the total bacterial biomass was significantly higher in summer. A complex bacterial response to organic matter inputs and availability was observed. In the S. Aegean, during the summer period (September 1997) of reduced sedimentation rates and (hence) reduced food availability, bacteria utilise only the sedimentary organic matter which they hydrolyse through ectoenzymatic activity. In the early spring (March 1997), however, when fresher and labile organic matter is available, enzymatic activity is reduced. In agreement with the above, bacterial biomass (also, as Adeno TriPhoshoric acid-ATP) during summer appears to be higher in the North than in the S. Aegean. Bacterial density coupled with total mass and protein fluxes indicate a rapid bacterial response to pelagic production. Bacterial biomass was significantly correlated with sedimentary protein and phytopigment concentrations reflecting a clear response of bacteria production to the rates of accumulation of labile organic compounds in the surface sediments. Carbon mineralisation rates (carbon production) were an order of magnitude higher than in the S. Aegean during both seasons (March and September 1997)

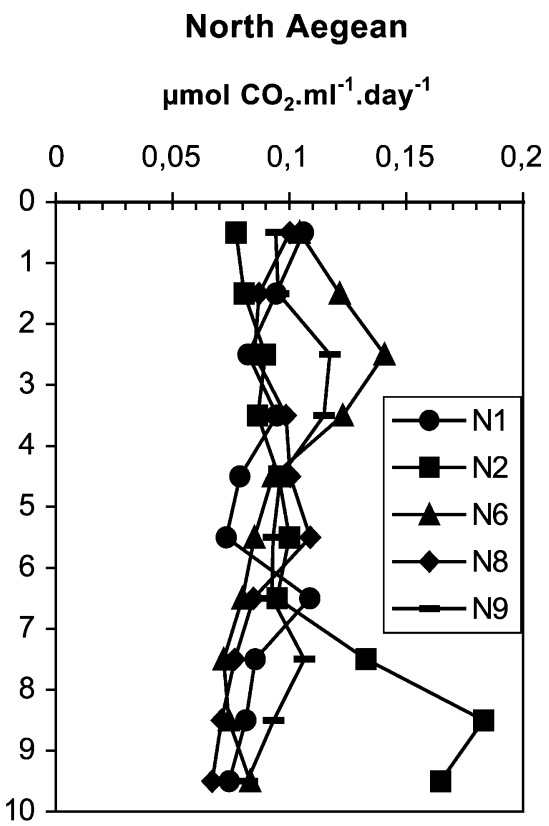

Fig. 13. Vertical profiles of $\mathrm{CO}_{2}$ production (carbon mineralisation), at selected sampling stations from the N. and $\mathrm{S}$. Aegean basins. 
(Fig. 13); proteolytic activity was half that recorded in the south, during the same period. Overall, potential hydrolysis rates of High Molecular Weight Compounds (HMWC) and mineralisation rates of labile Low Molecular Weight Compounds (LMWC) displayed the opposite, but complementary, trend through time and space for all the areas. All the data appear to confirm the inhibition of bacterial enzymatic activity by readily utilizable LMWC. Principal component analysis undertaken on the September 1997 data has suggested that the increase in the mineralisation rates of LMWC coincides with an increase in the ATP-content. This relationship could be due to the protozoa (Danovaro et al., 1998) and meiofauna (Danovaro et al., 1999a) responding to the readily available OM, after bacterial enzymatic activity has taken place. The data from the Aegean Sea show that the hydrolysis rate of macromolecular compounds, together with the mineralisation rate of labile monomers, follow frequently an opposite evolution through time and space. Independent calculations were carried out to estimate the efficiency of the benthic bacteria, in exploiting protein pools from the North and S. Aegean (estimated as amounts of proteins available, per unit of bacterial biomass). A constant value of about $70 \mu \mathrm{g}$ proteins $\mu \mathrm{g} \mathrm{C}^{-1}$ of bacterial biomass in all areas and at both seasons was measured; this suggests that the two systems exploit the protein pools with a very similar efficiency.

Analysis of surface sediments, with respect to $\delta^{13} \mathrm{C}$ and fatty acids, show that the sedimentary organic carbon in the South and the N. Aegean Basins is predominantly of marine origin. In-situ Sediment Community Oxygen Consumption (SCOC) measurements, by means of a benthic lander, revealed a consistent difference in mineralisation ( $\sim$ carbon input) between the southern and northern basins, with

Table 3

Sediment community oxygen consumption rates $\left(\mu \mathrm{mol} \mathrm{m} \mathrm{m}^{-2} \mathrm{~h}^{-1}\right)$, measured in-situ at selected stations from N. and S. Aegean Sea, during two contrasting periods

\begin{tabular}{llcl}
\hline Station & Depth $(\mathrm{m})$ & Summer 1997 & Spring 1998 \\
\hline MSB-1 & 1750 & 18 & 15 \\
MSB-2 & 1580 & 26 & 14 \\
MNB-1 & 1270 & 119 & 51 \\
MNB-2 & 975 & 53 & 53 \\
\hline
\end{tabular}

the highest value recorded in the N. Aegean (Table 3). This geographical trend was supported by total and diffusive oxygen fluxes, measured in shipboard incubated cores. Silicate fluxes measured in shipboard incubation cores showed the same north to south difference as the SCOC values, indicating a consistent difference in biogenic silica input (diatoms). Chlorophyll- $a$ inventories in the surface sediment, reflecting the presence of non-degraded algal matter, were clearly higher in the N. Aegean Basins and show that the sediments in these basins contain significantly increased Labile Organic Matter (LOM). Such a conclusion is entirely consistent with the results obtained on SCOC rates and LOM fluxes.

Total meiofaunal abundance was related inversely with depth in the S. Aegean; however, the pattern in the N. Aegean was opposite. The numbers of individuals are fairly higher in the N. Aegean, with the maximum found at the deepest Stn MNB-1 (9541437 ind $10 \mathrm{~cm}^{-2}$ at $1290 \mathrm{~m}$ ) (Fig. 14). In contrast, much lower values (2 to 8 times lower) are reported for the S. Aegean and are comparable to those (136 ind $10 \mathrm{~cm}^{-2}$ ) reported by Danovaro et al. (1995, 2000a) from the same area. Total meiofauna biomass ranged from 1.8 to $170 \mu \mathrm{g} \mathrm{C} 10 \mathrm{~cm}^{-2}$ in the $\mathrm{S}$. Aegean (mean $58.6 \mu \mathrm{g} \mathrm{C} 10 \mathrm{~cm}^{-2}$ ) and from 28-595 $\mu \mathrm{g} \mathrm{C} 10 \mathrm{~cm}^{-2}$ (mean $239 \mu \mathrm{g} \mathrm{C} 10 \mathrm{~cm}^{-2}$ ) in the $\mathrm{N}$. Aegean. In general, there was a lack of significant seasonal changes in meiofaunal densities in the deep stations of the Aegean. However, the analysis of the spatial distribution of meiobenthos in the Aegean indicates that meiofaunal distribution is very heterogeneous in the north, due mainly to the differential sedimentation of phytodetritus. In this respect, the N. Aegean could be considered, in comparison to its southern counterpart, as a more dynamic system experiencing higher fluctuations in organic matter availability.

As evidenced by the meiofaunal, macrofaunal and megafaunal analysis (the latter by means of deep benthic video observations), Stn MNB-1 in the Limnos Basin (1290 m water depth) is characterised by high diversity and density values and, as far as the N. Aegean is concerned, it could be considered as a benthic activity "hot spot" and natural depocentre of organic mater. Stn MNB-3, in the Central Aegean, is situated far from the influence of continental land masses; it was found to support much lower densities 

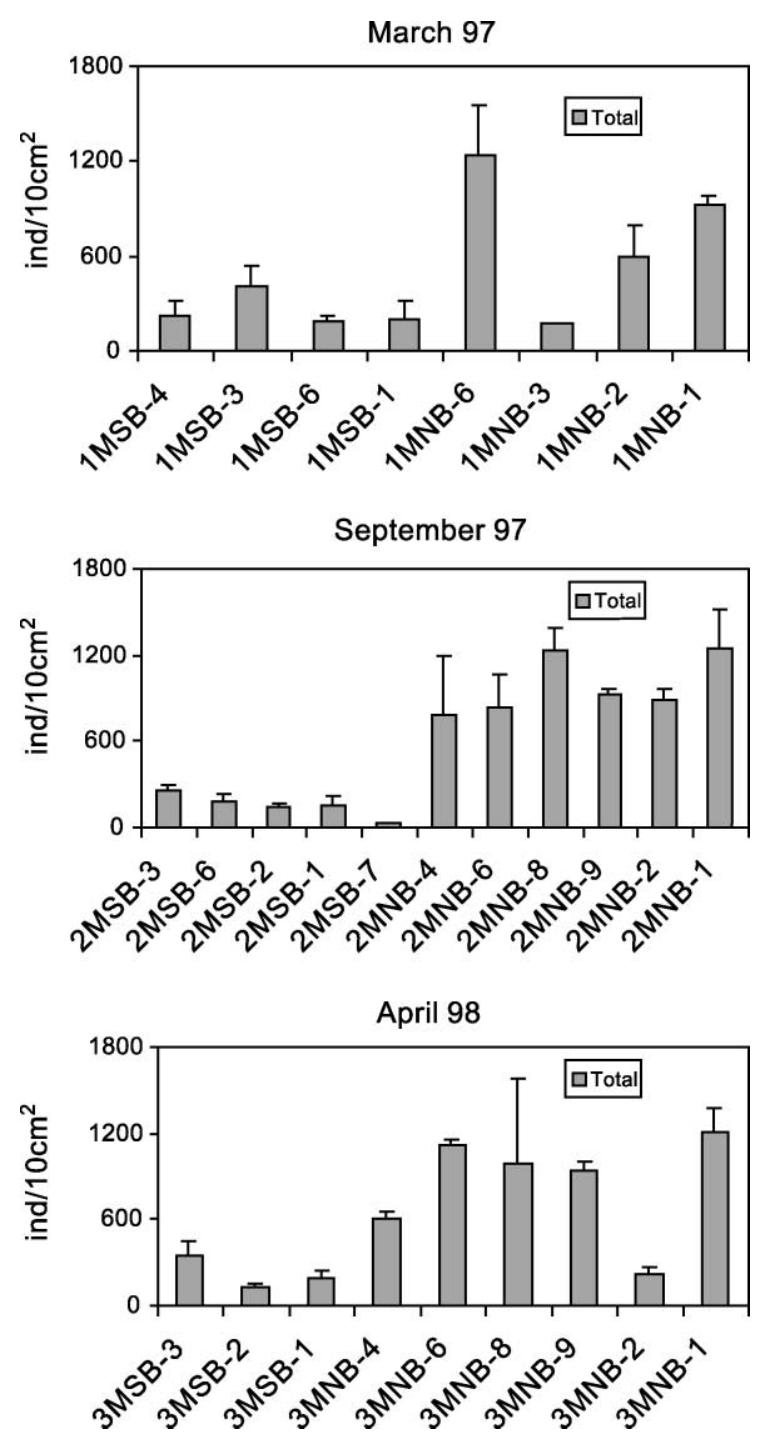

Fig. 14. Average number of total meiofauna per $10 \mathrm{~cm}^{2}$ ( \pm standard deviation), during contrasting periods from the N. and S. Aegean basins.

and diversity and, to a certain extent, biomass. Stations MSB-3 (1190 m water depth) and MSB-4 (900 $m$ water depth) in the western part of the S. Aegean have similar density and diversity values to station MNB-3 (800 m) in the central Aegean and 2-7 times higher values than any other S. Aegean station $(1280-2270 \mathrm{~m})$. This could be attributed to the decreasing availability of $\mathrm{OM}$ in the benthic zone from NE to SW Aegean and in a $\mathrm{W}-\mathrm{E}$ direction within the S. Aegean.

\section{Conclusions}

The recent integrated biogeochemical studies in the Aegean Sea ecosystem have provided important new information on the functional processes of the Aegean ecosystem. The major conclusions of these studies are summarised as follows.

(a) No new deep and bottom water formation in the Aegean Sea was observed during 1997-1998, mainly due to the mild winter conditions. Instead, intermediate water was formed during the same period. However, there is an indication of ventilation of the Cretan Sea waters down to 1500 dbar, by advection. Recent data (1987, 1990 and 1991) indicate significant dense water formation in the North and Central Aegean, implying possibly initiation of the Eastern Mediterranean Transient in the N. Aegean.

(b) The nutrient, POC, chlorophyll- $a$, phytoplankton and mesozooplankton abundance, primary production and bacteria production levels, although higher in the N. than in the S. Aegean, reflect clearly the highly oligotrophic character of the entire Aegean Sea.

(c) According to the carbon flow budget a microbial food web predominated in the entire Aegean Sea, the role of which was more significant in the $\mathrm{S}$. Aegean. However in the latter area mesozooplankton was revealed a multivorous grazing mode.

(d) Within the N. Aegean, there is no Black Sea Water (BSW) signature and influence in terms of nutrients, POC, particulate metals or trace elements. Instead, an important BSW signal was observed in certain dissolved phases, especially in the DOC and trace elements concentration (mainly $\mathrm{Mn}$ and to a lesser degree $\mathrm{Cd}, \mathrm{Cu}, \mathrm{Ni}$ ).

(e) In contrast to the small differences in biochemical characteristics within the euphotic zone, the downward material fluxes at mid-depth $(500 \mathrm{~m})$ are clearly higher in the N. Aegean than in the S. Aegean. Differences within these basins are related mostly to the presence of cyclonic and anticyclonic eddies and the down- or up-welling of the particulate matter. Substantially higher values of near-bottom mass fluxes were measured in the deep basins of the N. Aegean, implying significant deep lateral fluxes 
of POM; these originate, possibly, from sediment resuspension.

(f) The N. Aegean could be classified as a "continental margin" ecosystem, in relation to the high terrigenous fluxes and the neritic-pelagic character of mesozooplankton; in comparison, the S. Aegean is somewhat typical of an "oceanic margin" environment.

(g) In the Aegean Sea, there is a close relationship and, consequently, coupling between the near-bottom mass fluxes and the accumulation rates of organic matter, as well as benthic mineralisation, bioturbation, redox potential and oxygen consumption rates; likewise, sediment microbiological and enzymatic activity and the meio-macro- and mega faunal abundances. The N. Aegean is characterised by higher fluxes of labile POC and higher rates of benthic mineralisation. From this point of view, the N. Aegean displays much higher benthic productivity and diversity, relative to the S. Aegean. The deep isolated N. Aegean basins should be regarded as "hot spots" of organic matter accumulation, benthic abundances and diversity.

(h) A preliminary attempt using an integrated approach has been made to understand the variability of pelagic benthic coupling processes in the Aegean Sea. The observed variability is consistent with the initial hypothesis that higher pelagic primary productivity levels produce higher trophic inputs, to the deep sea benthos in the N. Aegean. Spatial heterogeneity in the organic content and biological activities in the S. Aegean sediments are more difficult to interpret, on the basis of water column biological processes. However, such variation may reflect complicated differences in sediment supply, particle transport, and variable resuspension rates implied by the different character of the North, relative to the South Aegean ("marginal" compared with "oceanic" system).

(i) There appears to be a $\mathrm{N}-\mathrm{S}$ gradient in the biogeochemical and benthic processes in the Aegean, although this gradient is not well defined and is not permanent throughout the year. There are differences between the northern and northeastern part of the $\mathrm{N}$. Aegean and the central and S. Aegean; these are especially pronounced during winter-early spring, being influenced by the marginal inputs and the Black Sea waters inflow into the Aegean. The $\mathrm{N}-\mathrm{S}$ gradient is also obscured by mesoscale eddies (cyclones-anti- cyclones) and water formation, which induces also an $\mathrm{E}-\mathrm{W}$ gradient in the $\mathrm{S}$. Aegean Sea.

\section{Acknowledgements}

This work is part of the MTP-II-MATER project funded by the EU under the MAST III/MTP-II contract MASTIII-CT96-0051. The officers and the crew the R/V AEGAEO are acknowledged gratefully for their important and effective contribution to the fieldwork and sampling. The two reviewers are also acknowledged by the authors for their suggestions, corrections and criticism that significantly upgraded the manuscript.

\section{References}

Balopoulos, E., Collins, M.B., 1999. Special Issue. Insights into the hydrodynamics and biogeochemistry of the S. Aegean, E. Mediterranean: the Pelagos (EU) project. Prog. Oceanogr. 44 (4), 469-699.

Berggreen, U., Hansen, B., Kiorboe, T., 1988. Food size spectra, ingestion and growth of copepod Acartia tonsa: implications for determination of copepod production. Mar. Biol. 99, 341-352.

Bligh, E.G., Dyer, W., 1959. A rapid method for total lipid extraction and purification. Can. J. Biochem. Physiol. 37, 911-917.

Christaki, U., Van Wambeke, F., Dolan, J.R., 1999. Nanoflagellates (mixotrophs, heterotrophs and autotrophs) in the oligotrophic Eastern Mediterranean: standing stocks, bacterivory and relationships with bacterial production. Mar. Ecol. Prog. Ser. 181, 297-307.

Chronis, G., Lykousis, V., Georgopoulos, D., Zervakis, V., Stavrakakis, S., Poulos, S., 2000. Suspeneded particulate matter and nepheloid layers in the Southern Margin of the Cretan Sea (NE Mediterranean): seasonal distribution and dynamics. Prog. Oceanogr. 46 (2-4), 163-165.

Coban-Yildiz, Y., Tugrul, S., Ediger, D., Yilmaz, A., Polat, S.C., 2000. A comparative study on the abundance and elemental composition of POM in three interconnected basins: the Black, the Marmara and the Mediterranean Seas. Med. Mar. Sci. 1 (1), $51-63$.

Danovaro, R., Serresi, M., 2000. Viral density and virus to bacterium ratio in deep-sea sediments of the eastern Mediterranean. Appl. Environ. Microbiol. 66 (5), 1857-1861.

Danovaro, R., Fabiano, M., Della Croce, N., 1993. Labile organic matter and microbial biomasses in deep-sea sediments (E. Mediterranean Sea). Deep-Sea Res. 40 (5), 953-965.

Danovaro, R., Croce, N.D., Eleftheriou, A., Fabiano, M., Papadopoulou, N., Smith, C., Tselepides, A., 1995. Meiofauna of the deep Eastern Mediterranean: distribution and abundance in relation to bacterial biomass, organic matter composition and other environmental factors. Prog. Oceanogr. 36, 329-341. 
Danovaro, D., Marrale, D., Della Croce, N., Dell'Anno, A., Fabiano, M., 1998. Heterotrophic nanoflagellates, bacteria and labile organic compounds in continental shelf and deep-sea sediments of the Eastern Mediterranean. Microbiol. Ecol. 35, 244-255.

Danovaro, R., Dell'Anno, A., Martorano, D., Parodi, P., Marrale, D., Fabiano, M., 1999a. Seasonal variation in the biochemical composition of deep-sea nematodes: bioenergetic and methodological considerations. Mar. Ecol. Prog. Ser. 179, 273-283.

Danovaro, R., Dell'Anno, A., Pusceddu, A., Fabiano, M., 1999b. Nucleic acid concentrations (DNA, RNA) in the continental and deep-sea sediments of the Eastern Mediterranean: relationships with seasonally varying organic inputs and bacterial dynamics. Deep-Sea Res., Part I 46, 1077-1094.

Danovaro, R., Dinet, A., Duineveld, G., Tselepides, A., 1999c. Benthic response to particulate fluxes in different trophic environments: a comparison between the Gulf of Lions-Catalan Sea (W-Mediterranean) and the Cretan Sea (E-Mediterranean). Prog. Oceanogr. 44, 287-312.

Danovaro, R., Marrale, D., Della Croce, N., Parodi, P., Fabiano, M., 1999d. Biochemical composition of sedimentary OM and bacterial distribution in the Aegean Sea: trophic state and pelagicbenthic coupling. J. Sea Res. 42, 117-129.

Danovaro, R., Marrale, D., Dell'Anno, A., Della Croce, N., Tselepides, A., Fabiano, M., 2000a. Bacterial response to seasonal changes in labile organic matter composition on the continental shelf and bathyal sediments of the Cretan Sea. Prog. Oceanogr. 46 (2-4), 345-366.

Danovaro, R., Tselepides, A., Otegui, A., Della Croce, N., $2000 \mathrm{~b}$. Dynamics of Meiofaunal assemblages on the continental shelf and deep-sea sediments of the south Aegean Sea (NE Mediterranean): relationships with seasonal changes in food supply. Prog. Oceanogr. 46 (2-4), 367-400.

de Wilde, P.A.W.J., Duineveld, G.C.A., Berghuis, E.M., Lavaleye, M.S.S., Kok, A., 1998. Late summer mass deposition of gelatinous phytodetritus along the slope of the NW European continental margin. Prog. Oceanogr. 42, 165-187.

Dubois, M., Gilles, K., Hamilton, J.K., Rebers, P.A., Smith, F., 1956. Colorimetric method for determination of sugars and related substances. Anal. Chem. 28, 350-356.

Georgopoulos, D., 2001. Water masses and dynamic structure in the Aegean. PhD Thesis, Univ. of Patras, Greece, unpublished, p 310.

Georgopoulos, D., Theocharis, A., Zodiatis, G., 1989. Intermediate water formation in the Cretan Sea (S. Aegean Sea). Oceanol. Acta 12 (4), 353-359.

Georgopoulos, D., Chronis, G., Zervakis, V., Lykousis, V., Poulos, S., Iona, A., 2000. Hydrology and circulation in the Southern Cretan Sea during the CINCS experiment (May 1994-September 1995). Prog. Oceanogr. 46 (2-4), 89-112.

Hartree, E.F., 1972. Determination of proteins: a modification of the Lowry method that give a linear photometric response. Anal. Biochem. 48, 422-427.

Hopcroft, R.R., Roff, J.C., Lombard, D., 1998. Production of tropical copepods in Kingston Harbour, Jamaica: the importance of small species. Mar. Ecol. Prog. Ser. 183, 29-38.

Hoppe, H.G., 1993. Use of fluorogenic model subtrates for extracellular enzyme activity (EEA) measurement of bacteria. In: Kemp, P.F., Sherr, B.F., Sherr, E.B., Cole, J.J. (Eds.), Handbook of Methods in Aquatic Microbial Ecology. Lewis Publishers, Ann Arbor, pp. 423-431.

Ignatiades, L., 1976. The standing stock of diatoms and dinoflagellates in the oligotrophic waters of of Southern Aegean Sea. Int. Rev. Gesamten Hydrobiol. 61, 193-199.

Ignatiades, L., 1998. The productive and optical status of the oligotrophic waters of Southern Aegean Sea (Cretan Sea) Eastern Mediterranean. J. Plankton Res. 20, 985-995.

Ignatiades, L., Georgopoulos, D., Karydis, M., 1995. Description of the phytoplanktonic community of the oligotrophic waters of the SE Aegean Sea (Mediterranean). P.S.Z.N.I: Mar. Ecol., 82-83.

Kallianiotis, A., Sophronidis, K., Vidoris, P., Tselepides, A., 2000. Demersal fish and megafauna assemblages in the Cretan continental shelf and slope (NE Mediterranean): seasonal variation in species density, biomass and diversity. Prog. Oceanogr. 46 (2-4), 429-455.

Kontoyiannis, H., Theocharis, A., Balopoulos, E., Kioroglou, S., Papadopoulos, V., Collins, M., Velegrakis, A.F., Iona, A., 1999. Water fluxes through the Cretan Arc Straits, Eastern Mediterranean Sea: March 1994-June 1995. Prog. Oceanogr. 44 (4), $511-529$.

Lacombe, H., Tsernia, P., Benoist, G., 1958. Contribution à l'étude hydrologique de la Mer Egée en période d'été. Bull. Inf. COEC 8, 454-468.

Latif, M.A., Ozsoy, E., Oguz, T., Unluata, U., 1991. Observations of the Mediterranean inflow into the Black Sea. Deep-Sea Res. 38 (Suppl. 2), 711-723.

Lykousis, V., 1998. Nepheloid layers and sources of SPM in the Aegean Sea. 3rd MTP-II Workshop, Rhodes, Greece, pp. 185187 Abstracts.

Mackas, D.L., Bohrer, R., 1976. Fluorescence analysis of zooplankton gut contents and an investigation of diel feeding patterns. J. Exp. Mar. Biol. Ecol. 25, 77-85.

Marsh, J.B., Weinstein, W.J., 1966. A simple charring method for determination of lipids. J. Lipid Res. 7, 574-576.

Moeseneder, M., Winter, C., Herndl, G.H., 2001. Horizontal and vertical complexity of attached and free-living bacteria of the eastern Mediterranean Sea determined by $16 \mathrm{~S}$ rDNA and 16S r RNA fingerprints. Limnol. Oceanogr. 46 (1), 95-107.

Nielsen, J.N., 1912. Hydrography of the Mediterranean and Adjacent Waters, in Report of the Danish Oceanographic Expedition 1908-1910 to the Mediterranean and Adjacent Waters, V. 1, Copenhagen, pp. 72-191.

Obernosterer, I., Reitner, B., Herndl, G.J., 1999. Contrasting effects of solar radiation on dissolved organic matter from different depths and its bioavailability to marine bacterioplankton. Limnol. Oceanogr. 44, 1645-1654.

Obernosterer, I., Kraay, G., de Ranitz, E., Herndl, G.J., 2000. Concentrations of low molecular weight carboxylic acids and carbonyl compounds in the Aegean Sea (Eastern Mediterranean) and the turnover of pyruvate. Aquat. Microb. Ecol. 20, 147-156.

Ovchinnikov, I.M., 1966. Circulation in the surface and intermediate layers of the Mediterranean. Oceanology 6, 48-59.

Ovchinnikov, I.M., Plakhin, E.A., Moskalenko, L.V., Neglyard, K.V., Osadchiy, A.S., Fedoseyev, A.F., Krivoshea, K.V., Voytova, K.V., 1976. Hydrology of the Mediterranean Sea. Gidrometeoizdat (edition), Leningrad, p. 283 (In Russian). 
Pitta, P., Giannakourou, A., 2000. Planktonic ciliates in the oligotrophic Eastern Mediterranean: vertical, spatial distribution and mixotrophy. Mar. Ecol. Prog. Ser. 194, 269-282.

Poulos, S.E., Drakopoulos, P.G., Collins, M.B., 1997. Seasonal variability in sea surface oceanographic conditions in the Aegean Sea (Eastern Mediterranean): an overview. J. Mar. Syst. 13, $225-244$.

Price, B., Lindsay, F.S., Pates, J.M., 1999. The biochemistry of major elements of the suspended particulate matter of the Cretan Sea. Prog. Oceanogr. 44 (4), 677-699.

Psarra, S., Tselepides, T., Ignatiades, L., 2000. Primary production in the oligotrophic Cretan Sea (NE Mediterranean): seasonal and interannual variability. Prog. Oceanogr. $46(2-4)$.

Roether, W., Schlitzer, R., 1991. Eastern Mediterranean deep water renewal on the basis of CFM and tritium data. Dyn. Atmos. Oceans $15,333-354$

Roether, W., Manca, B.B., Klein, B., Bregant, D., Georgopoulos, D., Beitzel, V., Kovačević, V., Luchetta, A., 1996. Recent changes in Eastern Mediterranean Deep Waters. Science 271, $333-335$.

Sempéré, R., Panagiotopoulos, G., Lafont, R., Marroni, B., Van Wambeke, F., 2002. Total Organic Carbon dynamics in the Aegean Sea. J. Mar. Syst. 33-34, 355-364 (this issue).

Simon, M., Azam, F., 1989. Protein content and protein synthesis rates of planktonic marine bacteria. Mar. Ecol. Prog. Ser. 51, $201-213$.

Siokou-Frangou, I., Pancucci-Papadopoulou, M.A., Kouyoufas, P., 1990. Etude de la repartition du zooplancton dans les mers Egee et Ionienne. Rapp. Comm. Int. Medit. 32 (1), 221.

Siokou-Frangou, I., Christou, E.D., Fragopoulu, N., Mazzocchi, M.G., 1997. Mesozooplankton distribution from Sicily to Cyprus (Eastern Mediterranean): II. Copepod assemblages. Oceanol. Acta 20 (3), 521-535.

Siokou-Frangou, I., Bianchi, M., Christaki, U., Christou, E., Giannakourou, A., Gotsis, O., Ignatiades, L., Pagou, K., Pitta, P., Psarra, S., Souvermezoglou, E., Van Wambeke, F., Zervakis, V., 2002. Carbon flow in the planktonic food web along a gradient of oligotrophy in the Aegean Sea (Mediterranean). J. Mar. Syst. 33-34, 335-353 (this issue).

Souvermezoglou, E., Krasakopoulou, E., Pavlidou, A., 1998. Nutrient regeneration and nutrient ratios in the N. Aegean sea (March-September 1997). 3rd MTP-II Workshop, Rhodes, Greece., pp. 185-187, Abstracts.

Souvermezoglou, E., Krasakopoulou, E., Pavlidou, A., 1999. Temporal variability in oxygen and nutrient concentrations in the $S$. Aegean sea and the Straits of the Cretan Arc. Prog. Oceanogr. 44 (4), 573-699.

Stanley, J., Perissoratis, C., 1977. Aegean ridge barrier and basin sedimentation patterns. Mar. Geol. 24, 97-107.

Stergiou, K.I., Christou, E.D., Georgopoulos, D., Zenetos, A., Souvermezoglou, C., 1977. The hellenic seas: physics, chemistry, biology and fisheries. Ansell, A.D., Gibson, R.N., Barnes, M. (Eds.), An Annual Review Oceanography and Marine Biology, vol. 35 , pp. $415-538$.

Strickland, J.D.H., Parsons, T.R., 1977. A practical handbook of seawater analysis. Fish. Res. Board Can. 167, 310 pp.

Sunda, W.G., Huntsman, S.A., Harvey, G.R., 1983. Photoreduction of manganese oxides in seawater and its geochemical and biological implications. Nature 301, 234-236.

Theocharis, A., Georgopoulos, D., 1993. Dense water formation over the Samothraki and Lemnos plateaux in the North Aegean Sea (Eastern Mediterranean Sea). Cont. Shelf Res. 13 (8/9), 919-939.

Theocharis, A., Georgopoulos, D., Lascaratos, A., Nittis, K., 1993. Water masses and circulation in the central region of the Eastern Mediterranean: Eastern Ionian, South Aegean and Northwest Levantine, 1986-87. Deep-Sea Res., Part II 40 (6), 1121-1142.

Theocharis, A., Balopoulos, E., Kioroglou, S., Kontoyiannis, H., Iona, A., 1999a. A synthesis of the circulation and hydrography of the South Aegean sea and the Straits of the Cretan Arc (March 1994-January 1995). In: Balopoulos, E., Collins, M.B. (Eds.), Insights into the Hydrodynamics and Biogeochemistry of the S. Aegean, E. Mediterranean: The Pelagos (EU) project. Prog. Oceanogr., vol. 44 (4), pp. 469-509.

Theocharis, A., Nittis, K., Kontoyiannis, H., Papageorgiou, E., Balopoulos, E., 1999b. Climatic changes in the Aegean Sea influence the Eastern Mediterranean thermohaline circulation (19861997). Geophys. Res. Lett. 26 (11), 1617-1620.

Tselepides, A., Polychronaki, T., 2000. The CINCS project: introduction. Prog. Oceanogr. 46 (2-4), 85-88.

Tselepides, A., Polychronaki, T., Marrale, D., Akoumianaki, I., Dell'Anno, A., Pusceddu, A., Danovaro, R., 2000a. Organic matter composition of the continental shelf and bathyal sediments of the Cretan Sea (NE Mediterranean). Prog. Oceanogr. 46 (2-4), 311-344.

Tselepides, A., Papadopoulou, N., Podaras, D., Plaiti, W., Koutsoubas, D., 2000b. Macrobenthic community structure over the continental margin of Crete (South Aegean Sea NE Mediterranean). Prog. Oceanogr. 46 (2-4), 401-428.

Ünlüata, U., Oguz, T., Latif, M.A., Öszoy, E., 1990. On the physical oceanography of the Turkish Straits. In: Pratt, L.J. (Ed.), The Physical Oceanography of Sea Straits. Kluwer Academic Publishing, Dordrecht, pp. 25-60.

Van Wambeke, F., Christaki, U., Bianchi, M., Psarra, S., Tselepides, A., 2000. Heterotrophic bacterial production in the Cretan Sea (NE Mediterranean). Prog. Oceanogr. 46 (2-4), 205-226.

Voutsinou-Taliadouri, F., Zeri, Chr., Ovsjany, E.I., Romanov, A.S., Moriki, A., 1999. Dissolved trace elements in an interrelated system: Black Sea and Aegean Sea. Proceedings International Conference Oceanography of the Eastern Mediterranean and Black Sea: Similarities and Differences of two Interconnected Basins, Athens, 23-26 February 1999, p. 39.

Voutsinou-Taliadouri, F., Zeri, C., Moriki, A., 2000. Distribution and transfer of trace elements in the Aegean seawater (E. Mediterranean Basin). Med. Mar. Sci. 1 (2), 5-13.

Zeri, C., Voutsinou-Taliadouri, F., Romanov, A.S., Ovsjany, E.I., Moriki, A., 2000. A comparative approach to dissolved trace element exchange in two interconnected basins: Black Sea and Aegean Sea. Mar. Pollut. Bull. 40 (8), 666-673.

Zervakis, V., Georgopoulos, D., Drakopoulos, P.G, 2000. The role of the North Aegean in triggering the recent Eastern Mediterranean climatic changes. J. Geophys. Res. 105 (C11), 26, 103-26, 116. 